\title{
Muğla-Yatağan Termik Santrali Emisyonlarının Etkisinde Kalan Tarım ve Orman Topraklarının Kirlilik Veri Tabanının Oluşturulması ve Emisyonların Vejetasyona Etkilerinin Araştırılması*
}

\author{
Generating Pollution Database of the Agricultural and Forest Soils Affected by Mugla- \\ Yatagan Coal-Fired Power Plant Emissions and Investigating Vegetation Effects
}

\author{
Koray HAKTANIR ${ }^{1}$, Sonay SÖZÜDOĞRU OK ${ }^{1}$, Ayten KARACA ${ }^{1}$, Sevinç ARCAK ${ }^{1}$, \\ Funda ÇIMEN ${ }^{2}$, Bülent TOPÇUOĞLU ${ }^{3}$, Cafer TÜRKMEN ${ }^{4}$, Hakan YILDIZ $^{5}$ \\ ${ }^{1}$ Ankara Üniversitesi, Ziraat Fakültesi, Toprak Bölümü, Ankara \\ ${ }^{2}$ Tarım Reformu Genel Müdürlü̈̆̈̈̈, Ankara \\ ${ }^{3}$ Akdeniz Üniversitesi, Teknik Bilimler MYO, Çevre Kirlenmesi ve Kontrolü Programı, Antalya \\ ${ }^{4}$ Onsekiz Mart Üniversitesi, Ziraat Fakültesi, Toprak Bölümü, Çanakkale \\ ${ }^{5}$ Tarım ve Köyişleri Bakanlığ
}

Özet: Bu araştırmada, Muğla-Yatağan Termik Santrali emisyonlarının santral çevresindeki tarım ve orman topraklarının ağır metal kapsamları üzerine etkileri araştırılmıştır. Bu amaçla hâkim rüzgar yönü ile diğer yönlerde olmak üzere santrale $721 \mathrm{~m}$ ile $15 \mathrm{~km}$ uzaklıkta değiş̧en mesafelerden 27 adet toprak ve 41 adet bitki örneği toplanmıştır. Toprak örneklerinde toplam ve alınabilir $\mathrm{Ni}, \mathrm{Cd}, \mathrm{Fe}, \mathrm{Cu}, \mathrm{Zn}, \mathrm{Mn}, \mathrm{S}$ ile bazı toprak özellikleri belirlenmiștir. Toprakların ağır metal ve S kapsamlarının santrale olan mesafe ile ilişkili olmadığı, daha çok hâkim rüzgâr yönüne bağlı olarak etkilendiği belirlenmiştir. Toprak örneklerinin ağır metal kapsamlarının toprak pH'sı ile ilişkili olduğu saptanmıştır. Toplam $\mathrm{Cd}$ ve $\mathrm{S}$ değerlerinin normal değerlerden oldukça yüksek olduğu görülmüştür. Toprakların ekstrakte edilebilir metal kapsamlarının genelde santralin güney ve güneybatı yönlerinde yüksek olduğu belirlenmiştir. Bitkilerde bulunan ağır metal miktarlarının yüksek olduğu saptanmıştır. Çam ağaçlarının iğne yapraklarında alınabilir S miktarı diğer bitkilerden daha yüksektir. Susam ve havuçta $\mathrm{Cu}$, $\mathrm{Cd}, \mathrm{Zn}$ oldukça yüksek bulunmuştur. Bu miktarların sebzeler için tüketilmesine izin verilen değerlerin üzerinde olduğu saptanmıştır. Biyolojik izleme bitkisi olarak değerlendirilen karayosununun ağır metal ve S kapsamının son derece yüksek olduğu görülmüştür.

Anahtar kelimeler: Yatağan, Termik santral, Emisyon, Uçucu kül, Ağır metal, Toprak, Bitki.

Abstract: In this study, the effect of emissions of Yatagan Coal Power plant on the heavy metal content of agricultural and forest soils surrounding of the central were investigated. For this purpose, 27 soil and 41 plant samples were collected, based on the dominant wind direction and the other directions, from the varying distances between $721 \mathrm{~m}$ and $15 \mathrm{~km}$ far from the central. Total and available $\mathrm{Ni}, \mathrm{Cd}, \mathrm{Fe}, \mathrm{Cu}, \mathrm{Zn}, \mathrm{Mn}$ and $\mathrm{S}$, and some properties of soil samples were determined. The results indicated that the heavy metal and $\mathrm{S}$ contamination were not related to the distances to the central, more, depending on the prevailing wind direction has been influenced. Soil $\mathrm{pH}$ also affected heavy metal content of the samples. Total Cd and $\mathrm{S}$ values were rather higher than that of normal values for soil and plants. It was determined that extractable heavy metals and $\mathrm{S}$ concentrations were high on the south and southeast part of the power plant. In plants high amounts of heavy metals were detected. Pinus trees accumulated available $S$ on their needle leaves in very high concentrations comparing to other plant samples. Sesame and carrot samples had highest $\mathrm{Cu}, \mathrm{Cd}$ and $\mathrm{Zn}$ content which were exceeded permitted limits for the edible vegetables. Extremely high amounts of heavy metal and $\mathrm{S}$ concentrations were determined in the moss which is considered as a biological monitoring plant.

Key words: Yatagan, Coal-fired power plant, Emissions, Flying ash, Heavy metal, Soil, Plant.

\section{Giriş}

Dünyada oldukça yaygın bir rezerv halinde bulunan linyit kömürü, artan petrol fiyatları karşısında hala önemli bir enerji kaynağı olma özelliğini sürdürmektedir. Ülkemiz linyitlerine dayalı elektrik üretimi tesislerinin kurulması, 1970'li y1llarda ortaya ç1kan petrol krizinden sonra hiz kazanmış olup, 2010 yılına kadar yapılan üretim planlamalarında da ağırlıklı biçimde yer almıştır. 2010 yılında ülkemizin taş kömürü ve linyit rezervlerinin \% 69'unun elektrik enerjisi üretiminde kullanılması hedeflenmiștir (Yıldız, 1996).

Ülkemizde termik santraller kurulurken hep olumlu yönleri vurgulanmış, neden olacağ birçok çevre sorunları gündem dışı tutulmuştur. Kömüre dayalı elektrik üretiminde artan kömür tüketimi

\footnotetext{
* Bu proje DPT tarafindan desteklenmiştir.
} 
termal kirliliği, parçacık dağılımını (sis), sülfür yayılışını, asit yağmurları, sera etkisini ve iz element yayılışını artırmaktadır.

Kömürün bileşimindeki iz elementler ve miktarları, kömür oluşumuna farklı kömürleşme basamaklarında dâhil olmalarına bağlı olarak farklılık göstermektedir. Kömürdeki elementlerin çoğu mineral madde ile birlikte bulunmaktadır. Bu minerallerin önemli bir kısmı yanmadan sonra küllerde konsantre olmaktadır (Gentzis ve Goodarzi, 1997). Santralde kömürün yanması sırasında organik maddenin kaybıyla birlikte açığa çıkan ve linyitin \% 13'ünü oluşturan kül de bu elementlerce zenginleşmektedir (Sawidis vd., 2001). Bu küllerin doğrudan toprak üzerinde depolanmas1 durumunda, kül içindeki zararlı bileşenlerin yağmur suları ile toprağa sızma ve yeraltı sularına karışma olasılığı bulunmaktadır. Diğer yandan santral bacalarından mikro partiküller halinde baca külleri yani uçucu küller çıkmaktadır. Yakılan kömürden arta kalan milyonlarca ton kül, cüruf ve partiküller birkaç yüz metre yükseklikte ve binlerce hektar genişlikte başka bir arazi üzerine depo edildiğinde ormanları, maki alanlarını, tarım kültürlerini ve yerleşim alanlarını yoğun kül emisyonu altında bırakmaktadır (Karaca, 1997).

Pacyna (1982), Avrupa ülkelerinde kömürle çalışan termik santrallerin atmosfere verdiği ağır metal ve iz element miktarlarını, kullanılan linyitin uçucu kül yüzdesine bağlı olarak emisyon faktörü ile belirlemiş ve en yüksek değerleri Romanya, Yugoslavya ve Türkiye'de kullanılan linyitlerin içerdiğini saptamıştır. Bunun nedeninin ise bu ülkelerde bulunan termik santrallerde kullanılan linyitlerin kül kapsamlarının çok fazla olmasından kaynaklandığını açıklamıştır.

Yatağan Termik Santralinin Muğla-Yatağan yöresinde orman toprağı ve ağaçları üzerine etkisinin araştırılması sonucu yöre topraklarında ve bu topraklar üzerinde yetişen Kızılçam (Pinus brutia) yapraklarında belirlenen toplam kükürt değerlerinin kabul edilebilir değerlerin çok üstünde olduğu tespit edilmiştir (Sarıgül, 1991). Ayrıca topraktaki kükürt miktarının artmasıyla birlikte Kızılçam ibrelerinin kükürt kapsamlarının da arttığı dolayısıyla ağaçların hava kirliliğinden etkilenme derecelerinin kirletici kaynağa uzaklığa, bakıya, yükseltiye ve yöredeki hâkim rüzgâr yönüne bağl1 olduğu belirtilmiştir.

Yapılan bir araştırma ile Yatağan termik santralinde kullanılan kömürlerin nem içeriğinin \% 32, kuru nem içeriğinin \% 10.6, kül kapsamının \% 39, buharlaşabilir madde miktarının \% 33, C'nun \% 33.8, fikse edilmiş C'nun \% 18, toplam S'ün \% 2.6, H'nin \% 2.1, N'un \% 0.8, O'nin \% 22 olduğu; mineral madde kapsamının (kuru ağırlı olarak); \% 2.3 illit, \% 5 kaolinit/klorit, \% 16.3 kuvars, \% 11 kalsit, \%1.6 pirit, \% 0.3 jips, \% 36.6 toplam minerallerden oluştuğu belirlenmiştir (Karayiğit vd., 2000).

Sivas-Kangal, Çayırhan, Tavşanlı, Tunçbilek, Soma-B, Seyitömer ve Yatağan olmak üzere 7 termik santralden alınan uçucu kül örneklerinde yapılan analizlerde $\mathrm{S}, \mathrm{Ca}, \mathrm{Mg}$ ve Fe'in tüm santral örneklerinde bulunduğu ve bu elementlerin uçucu küllerin temel bileşenlerini oluşturduğu belirlenmiştir. Ca'un uçucu külde bulunması linyitin yanması sırasında bacadan çıkan dumanda sülfür dioksitin oluşumunu engellediği için istenilen bir durumdur. Ayrıca Na, K, S, Al ve Ti elementleri de önemli düzeyde bulunmaktadır (Nuhoğlu ve Bülbül, 2003).

Kantarcı (2003), Yatağan, Kemerköy ve Yeniköy Termik Santrallerinin çevrelerinde bulunan ormanlık alanları önemli derecede etkilediğini ve ağaçlarda ekonomik kayıplara yol açacak düzeyde sararma ve kurumaların olduğunu belirtmiştir.

Karaca vd. (2007), Seyitömer termik santrali çevresi topraklarında ve yine Karaca vd. (2008) Afşin-Elbistan Termik Santrali çevresinde yapmış oldukları çalışmalarda, araştırma topraklarının çoğunluğunun Ni ve Cr kapsamlarının Toprak Kirliliği Kontrol Yönetmeliği sınır değerlerinin üstünde olduğunu belirtmişlerdir. Araştırmacılar, bu gibi durumlarda toprakta yüksek miktarda mevcut Ni ve $\mathrm{Cr}$ gibi elementlerin santral emisyonlarından $\mathrm{m} 1$ yoksa toprağı oluşturan ana materyalden mi kaynaklandığı noktasında bir ayrıma gitmek gerektiğini ve bunun içinde o alanın jeolojik açıdan da araştırılması gerektiğini vurgulamışlardır.

Yukarıda belirtilen açıklamalar doğrultusunda linyit kömürü kullanılarak enerji üretimi yapılan Yatağan Termik Santralinin çevresinde mevcut tarım topraklarının pH, EC, organik madde, 
ağır metal, iz element ve kükürt kapsamları ile bölgede yetişen bazı bitki çeşitlerinin iz element ve ağır metal kapsamları üzerine olası etkilerinin ortaya konulması bu çalışmanın amacını oluşturmaktadır.

\section{Materyal ve Yöntem}

\subsection{Santralin Fiziki Coğrafya Özellikleri}

Yatağan Termik santrali, Muğla yöresinde bulunan 800 milyon tonluk düşük kalorili linyitin değerlendirilerek elektrik enerjisi üretilmesi amacı ile kurulmuştur. Muğla yöresi, Afşin-Elbistan kömür havzasından sonra ülkemizin en önemli kömür havzalarından birisidir. I. Ünitesi 1982, II. Ünitesi 1983 ve III. Ünitesi 1984 y1lında devreye sokulan santralin 2 km uzaklıkta $309800 \mathrm{~m}^{2}$ lik bir alanda kül stok sahası mevcuttur.

Yatağan termik santrali, Yatağan-Milas karayolunun kuzeyinde, Yatağan ilçesine $3 \mathrm{~km}$ uzaklıktaki Yatağan ovasında yer almakta olup, $1163000 \mathrm{~m}^{2}$ 'lik bir alan kaplamaktadır. Bu ovanın rakımı $325 \mathrm{~m}$ iken ovanın kuzeyinde Yatağan tepesinde $718 \mathrm{~m}$, kuzeybatıda Aladağ tepesinde $776 \mathrm{~m}$, güneyde Bakladağ tepesinde 778 m, Akdağ tepesinde 1210 m, ve Kocakarlık tepesinde 1396 m'dir. Dolayısılyla küçük bir ova düzlüğü ve bu düzlüğü çevreleyen tepe ve dağlardan oluşan Yatağan yöresinde jeolojik yapı neojen yaşlı marn ve gölsel (lakustrin) yumuşak kalkerler ile permienmesozoik yaşlı jerizitli-kloritli şistlerden ve sert kalkerlerden oluşmaktadır (Günay, 1986).

Yatağan termik santralinin etkisi altında bulunan topraklar genel olarak kollüviyal özellikte olup, Kırmızı Kahverengi Akdeniz büyük toprak grubuna girmektedir. Eğimleri \% 2-6 arasında değişmekte olan bu topraklar genelde killi tın bünyede ve orta ve derin profillere sahip bulunmaktadırlar. Topraklar hafif alkali özelliktedir. Ormanlık bölgede ise Kahverengi orman ve Kireçsiz Kahverengi orman toprakları yaygındır. Eğimi \% 6-12 ile daha dik arasında değişen, sığ, kaba bünyeli ve orta derecede erozyona sahip topraklardır. Topraklar asit ve hafif alkali özelliktedir (Özbek, 1996).

\subsection{Toprak Örneklerinin Alınması ve Analize Hazırlanması}

Örnekleme yerleri santrale olan uzaklık, hakim rüzgar yönü ve en yakın ormanlık alanın genel durumu dikkate alınarak belirlenmiştir. Hakim rüzgar yön, o bölgede rüzgarın en sıklıkla estiği yön olarak ele alınmakta ve bu tanım çerçevesinde, Devlet Meteoroloji İşleri Genel Müdürlüğünden elde edilen 2000-2004 yıllarına ait aylık ortalama verilere göre hakim rüzgar yönü kuzeyden güneye doğrudur. Bölgede hakim rüzgar yönü dışında rüzgarın 2. ve 3. sıklıkla estiği yönler ise kuzeydoğudan güneybatıya ve kuzeybatıdan güneydoğuya doğrudur. Emisyonların hakim rüzgar yönünde hareket edeceği göz önüne alınarak, güneyden 1-5, 7-15, 17,18 ve 19 no'lu örnekler olmak üzere tarım ve orman alanlarından 17 adet toprak örneği alınmıştır. Meteorolojik verilere göre, bölgede hakim rüzgar yön dışında rüzgarın 2. sıklıkla estiği yön olan güneybatı yönünden 20 no'lu örnek, rüzgarın üçüncü sıklıkla estiği yön olan güneydoğu yönünden de 6 ve 16 no'lu örnekler alınmıştır. Ayrıca 21-27 no'lu örnekler de tam tersi yönde kuzeybatıdan alınmıştır. Toprak örneklerinin alınmasında Bölge Orman Müdürlüğünün belirlemiş olduğu orman zararlanma alanları da dikkate alınmıştır. Toprak ve bitki örneklerinin alındığ 1 yerler Şekil 1 ve Çizelge 1'de, verilmiştir. Toprak örneklerinin alınma mesafeleri santrale en yakın olarak $721 \mathrm{~m}$, en uzak olarak $14903 \mathrm{~m}$ arasında değişmektedir.

Toprak örneklerinin her biri $0-20 \mathrm{~cm}$ 'den alındıktan sonra naylon torbalara konularak laboratuara getirilmiştir. Havada kurutulan toprak örnekleri ögütüldükten sonra $2 \mathrm{~mm}$ 'lik elekten elenmiş ve fiziksel ve kimyasal analizler için hazır hale getirilmiştir. Toprak örneklerinin alınması sırasında arazi üzerinde mevcut, tarımı yapılan kültür bitkileri ve orman vejetasyonu örneklerinden tesadüfî örnekleme yapılmıştır. Örneklemeler 2002 yılında yapılmıştır ve veriler 2002 yılına ait verilerdir.

Bitki örnekleri laboratuarda saf sudan geçirildikten sonra $65^{\circ} \mathrm{C}$ de kurutulmuş, plastik ağızlı değirmende ögütülmüştür. Toprak örneklerinde organik madde Walkley-Black yöntemine göre (Jackson, 1962), toprak reaksiyonu (pH) 1:2,5 toprak/su süspansiyonunda (Richards, 1954) 
belirlenmiştir. Toprak ve bitkide toplam kükürt Elttra CS 500 Carbon Sulfur Determinator cihazında $1450{ }^{\circ} \mathrm{C}$ 'de yakma ile saptanmıştır

Toplam $\mathrm{Cd}, \mathrm{Pb}$ ve Ni değerleri, toprak ve bitki örnekleri $\mathrm{HNO}_{3}-\mathrm{HCl}$ karışımında $(1: 3 \mathrm{v} / \mathrm{v}$ oranında) yaş yakılarak ve Atomik Absorpsiyon Spektrofotometresinde okunarak belirelenmiş̧ir (AAS- Shimadzu AA-625-01) (Kacar, 1995), alınabilir $\mathrm{Cd}$, $\mathrm{Pb}$ ve $\mathrm{Ni}$ ise $\mathrm{DTPA}+\mathrm{CaCl}_{2}$ ile ekstrakte edilen örneklerin AAS (Shimadzu AA-625-01) cihazında okunmasıyla saptanmıştır (Lindsay ve Norvell,1978) .

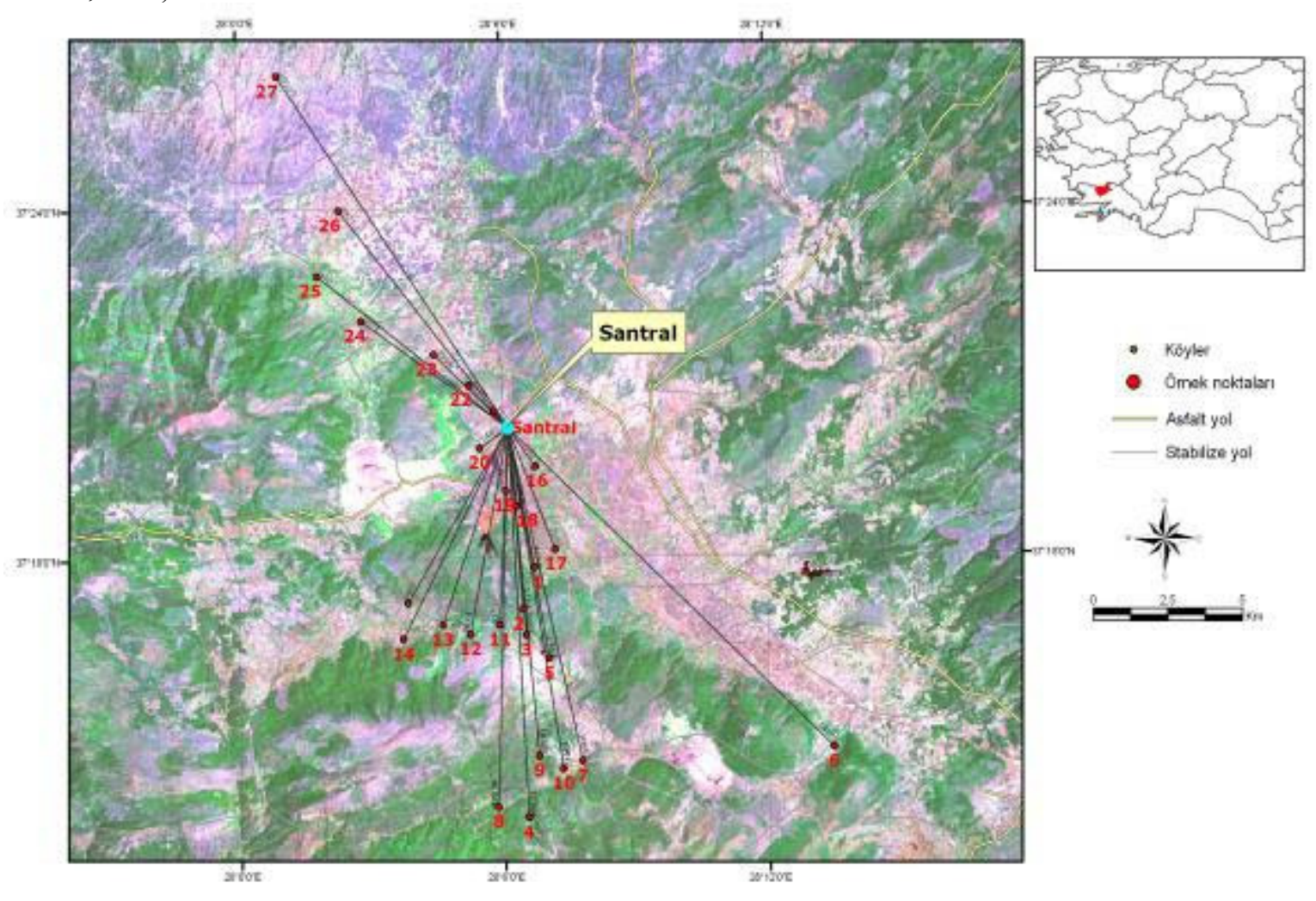

Şekil 1.Santral ve toprak örneklerinin alındığı noktalar.

\section{Bulgular ve Tartışma}

\subsection{Araştırma Topraklarının Bazı Özellikleri}

Toprak örneklerinin $\mathrm{pH}, \mathrm{EC}$, kireç, organik madde ve azot içerikleri Çizelge 2'de verilmiştir. Araştırma topraklarının $\mathrm{pH}$ değerleri 4,68-7,52 arasında değişim göstermiştir. Genel olarak orman topraklarının pH'larının çok kuvvetli asit ve kuvvetli asit (4.79-5.19), tarım topraklarının $\mathrm{pH}$ değerleri ise nötr veya hafif alkalin karakterdedir (Sağlam, 1997).

Santralden alınan kül örneğinin pH's1 çok yüksek alkali değerde 12.9'dur. Yatağan termik santralinin emisyon zararlanmalarının ele alındığı bir araştırmada, emisyon etkisi altında kalan orman serilerinde $0-5 \mathrm{~cm}$ 'lik toprak katmanlarında asitleşme eğilimi belirlendiği ifade edilmiştir (Sarıgül, 1991).

Araştırma topraklarının elektriksel iletkenlik değerleri 0,054-0,179 $\mathrm{dSm}^{-1}$ arasında değişmekte ve tuzluluk sinıflamasında tuzsuz grubuna girmektedir (Usta, 1995). Genelde toprakların kireç kapsamları \% 0-57.1 arasında değerler göstermiş, 6, 20, 22, 23, 25 no'lu örnekler hariç düşük bulunmuştur. Genelde pH'sı düşük orman topraklarında kireç saptanmamıştır. 1-3,7,9-18,27 no'lu örnekler kireçsiz; 4,19,26 (az kireçli); 5 orta kireçli; 6, 22, 25 çok kireçli; 8, 24 kireçli; 20 ve 23 çok fazla kireçli; 21 kireçli özellik göstermektedir (Kacar, 1995). Külün kireç kapsamı \% 7.65 olup orta kireçli sınıfına girmektedir. 
Toprakların organik madde kapsamları \% 0.71-5.07 arasında değişmekte, orman alanlarının organik madde kapsamının yüksek olmasına rağmen tarım alanlarının organik madde kapsamları yetersiz bulunmaktadır. Toprak örneklerinin toplam azot değerleri (\% 0,07-0.80) düşüktür.

Çizelge 1. Toprak ve Bitki Örneklerinin alındığı yerler.

\begin{tabular}{|c|c|c|c|c|c|c|c|c|}
\hline & Yer & Mevki & $\begin{array}{c}\text { Koordinat } \\
\text { Boylam }\end{array}$ & $\begin{array}{c}\text { Koordinat } \\
\text { Enlem }\end{array}$ & $\begin{array}{l}\text { Santrala } \\
\text { Uzaklık } \\
\text { (m) }\end{array}$ & $\begin{array}{l}\text { Yükseklik } \\
\text { (m) }\end{array}$ & Bitki & $\begin{array}{c}\text { Örnek alma } \\
\text { yeri }\end{array}$ \\
\hline & Santral & & 597633 & 4132842 & & 355 & & \\
\hline 1 & Kapubağ & Yanacak & 598534 & 4128412 & 4521 & 520 & Zeytin & Zeytinlik \\
\hline 2 & Bağyaka & Aladağ & 598156 & 4127092 & 5774 & 480 & İğne yapraklı & Orman \\
\hline 3 & Bağyaka & Havdan & 598259 & 4126265 & 6607 & 595 & $\begin{array}{c}\text { İğne yaprakl1, } \\
\text { incir yaprağ1 }\end{array}$ & Orman \\
\hline 4 & Bağyaka & Havdan & 598357 & 412048 & 12384 & 581 & Anız & $\begin{array}{l}\text { Orman içi } \\
\text { tarım alanı }\end{array}$ \\
\hline 5 & - & Yurttepe & 599022 & 4125529 & 7444 & 651 & $\begin{array}{c}\text { Misir anızi, } \\
\text { 1lgin }\end{array}$ & $\begin{array}{l}\text { Orman içi } \\
\text { tarım alanı }\end{array}$ \\
\hline 6 & Tinaz & $\begin{array}{l}\text { Selvili } \\
\text { Çeşme }\end{array}$ & 608598 & 4122750 & 14903 & 444 & $\begin{array}{c}\text { İğne yaprakl1, } \\
\text { tütün yaprağ1 }\end{array}$ & $\begin{array}{l}\text { Orman içi } \\
\text { tarım alanı }\end{array}$ \\
\hline 7 & Çaybükü & Yayla & 600158 & 4122278 & 10862 & 493 & $\begin{array}{c}\text { Anız, zeytin, } \\
\text { çam }\end{array}$ & $\begin{array}{l}\text { Orman içi } \\
\text { tarım alanı }\end{array}$ \\
\hline 8 & Çukuröz & Yarpınar & 597335 & 4120807 & 12039 & 568 & $\begin{array}{l}\text { Kızılçam } \\
\text { ibresi, iğne } \\
\text { yaprak, }\end{array}$ & Orman \\
\hline 9 & Çukuröz & Akyar & 598711 & 4122436 & 10462 & 534 & Çam, piren & Orman \\
\hline 10 & Çukuröz & Akyar & 599521 & 4122029 & 10977 & 486 & Misir & Tarım alanı \\
\hline 11 & Bağyaka & $\begin{array}{c}\text { Helvacı } \\
\text { Yarı }\end{array}$ & 597373 & 4126593 & 6255 & 477 & $\begin{array}{c}\text { Çam, pırnal } \\
\text { meşesi }\end{array}$ & Orman \\
\hline 12 & Bağyaka & Erincik & 596377 & 4126287 & 6674 & 506 & $\begin{array}{c}\text { İğne yaprak, } \\
\text { karaselvi, } \\
\text { akasya }\end{array}$ & Orman \\
\hline 13 & Cazkırlar & Beşpınar & 595462 & 4126583 & 6625 & 486 & $\begin{array}{c}\text { Pırnal meşesi, } \\
\text { çam ibresi }\end{array}$ & Orman \\
\hline 14 & Cazkırlar & Delikavak & 594142 & 4126120 & 7575 & 520 & Buğday anızı & $\begin{array}{l}\text { Orman içi } \\
\text { tarım alanı }\end{array}$ \\
\hline 15 & Cazkırlar & Işıkdamı & 594302 & 4127276 & 6487 & 483 & Pırnal meşesi & Orman \\
\hline 16 & Şahinler & Bahçeüstü & 598555 & 4131627 & 1525 & 344 & $\begin{array}{c}\text { Anız, piyam, } \\
\text { zeytin, pamuk }\end{array}$ & Tarım alanı \\
\hline 17 & Bozüyük & Tozlukahve & 599216 & 4128991 & 4164 & 431 & Misir & Tarım alanı \\
\hline 18 & Kapudağ & Çalış & 597953 & 4130362 & 2501 & 365 & $\begin{array}{l}\text { Misır (alt ve } \\
\text { üst yaprak) }\end{array}$ & Tarım alanı \\
\hline 19 & Kapudağ & Çalış & 597560 & 4130841 & 2002 & 370 & $\begin{array}{c}\text { Havuç (yaprak } \\
\text { ve kök) }\end{array}$ & Tarım alanı \\
\hline 20 & $\begin{array}{l}\text { Şahinler } \\
\text { Köyü İçi }\end{array}$ & & 596690 & 4132195 & 1144 & 390 & $\begin{array}{c}\text { Sirken ve } \\
\text { kökü }\end{array}$ & Tarım alanı \\
\hline 21 & $\begin{array}{c}\text { Turgut } \\
\text { Yolu }\end{array}$ & Yeniköy & 597150 & 4133377 & 721 & 340 & Susam & Tarım alanı \\
\hline 22 & $\begin{array}{l}\text { Turgut } \\
\text { Yolu }\end{array}$ & Yeniköy & 596321 & 4134189 & 1880 & 380 & Zeytin & Zeytinlik \\
\hline 23 & $\begin{array}{c}\text { Yeşil } \\
\text { Bağcilar } \\
\end{array}$ & Dağdibi & 595148 & 4135154 & 3394 & 398 & Anız & Tarım alanı \\
\hline 24 & $\begin{array}{c}\text { Yeşil } \\
\text { Bağcilar }\end{array}$ & Bozukbağ & 592706 & 4136215 & 5971 & 450 & Zeytin & Tarım alanı \\
\hline 25 & $\begin{array}{l}\text { Turgut } \\
\text { Çıkışı } \\
\end{array}$ & Musluk & 591220 & 4137635 & 8007 & 497 & $\begin{array}{l}\text { Domates, } \\
\text { patlican }\end{array}$ & Tarım alanı \\
\hline
\end{tabular}




\begin{tabular}{|c|c|c|c|c|c|c|c|c|}
\hline 26 & Turgut & Yortan & 591943 & 4139713 & 8921 & 340 & Akdar1 & Tarım alanı \\
\hline 27 & $\begin{array}{c}\text { Yeşil } \\
\text { bağcılar }\end{array}$ & Bozukbağ & 589836 & 4143976 & 13593 & 549 & Zeytin & zeytinlik \\
\hline
\end{tabular}

Çizelge 2. Toprakların bazı kimyasal özellikleri.

\begin{tabular}{|c|c|c|c|c|c|}
\hline $\begin{array}{c}\text { Örnek } \\
\text { No }\end{array}$ & $\begin{array}{c}\mathrm{pH} \\
(1: 2.5)\end{array}$ & $\begin{array}{c}\mathrm{EC} \mathrm{dSm}^{-1} \\
(1: 2.5)\end{array}$ & $\begin{array}{l}\mathrm{N} \\
\%\end{array}$ & $\begin{array}{l}\mathrm{OM} \\
(\%)\end{array}$ & $\begin{array}{c}\mathrm{CaCO}_{3} \\
(\%)\end{array}$ \\
\hline 1 & 4,83 & 0,094 & 0,16 & 1,87 & 0,0 \\
\hline 2 & 4,79 & 0,123 & 0,26 & 2,67 & 0,0 \\
\hline 3 & 5,19 & 0,104 & 0,24 & 2,91 & 0,0 \\
\hline 4 & 7,23 & 0,120 & 0,12 & 1,01 & 2,80 \\
\hline 5 & 7,28 & 0,134 & 0,08 & 0,81 & 4,96 \\
\hline 6 & 7,41 & 0,159 & 0,20 & 2,81 & 23,9 \\
\hline 7 & 7,52 & 0,091 & 0,10 & 1,31 & 1,00 \\
\hline 8 & 7,03 & 0,190 & 0,80 & 6.52 & 10,2 \\
\hline 9 & 5,41 & 0,054 & 0,11 & 1,24 & 0,0 \\
\hline 10 & 6,77 & 0,083 & 0,10 & 1,01 & 0,0 \\
\hline 11 & 4,82 & 0,158 & 0,61 & 5,07 & 0,0 \\
\hline 12 & 5,10 & 0,064 & 0,69 & 3,06 & 0,0 \\
\hline 13 & 5,43 & 0,064 & 0,21 & 2,75 & 0,0 \\
\hline 14 & 4,68 & 59,2 & 0,15 & 0,87 & 0,0 \\
\hline 15 & 5,55 & 76,4 & 0,12 & 1,75 & 0,0 \\
\hline 16 & 7,16 & 129,7 & 0,17 & 1,95 & 0,91 \\
\hline 17 & 6,77 & 125,6 & 0,07 & 1,28 & 1,42 \\
\hline 18 & 6,14 & 138,8 & 0,11 & 0,97 & 0,26 \\
\hline 19 & 6,88 & 172,3 & 0,23 & 1,86 & 3,73 \\
\hline 20 & 7,40 & 147,0 & 0,21 & 2,60 & 57,1 \\
\hline 21 & 7,49 & 179,2 & 0,24 & 0,98 & 13,4 \\
\hline 22 & 7,46 & 126,3 & 0,10 & 1,15 & 36,6 \\
\hline 23 & 7,51 & 140,7 & 0,19 & 0,84 & 50,7 \\
\hline 24 & 7,17 & 142,5 & 0,18 & 2,73 & 12,4 \\
\hline 25 & 7,09 & 142,5 & 0,18 & 1,86 & 32,6 \\
\hline 26 & 7,37 & 121,3 & 0,08 & 0,71 & 2,20 \\
\hline 27 & 5,69 & 68,7 & 0,11 & 2,13 & 0,15 \\
\hline Kül & 12,9 & 7,65 & 0,03 & 0,30 & 7,65 \\
\hline
\end{tabular}

3.2. Araştırma Topraklarının Toplam Pb, Ni, Cd, Fe, Cu, Zn, Mn ve S Kapsamları

Toprak örneklerinde ve kül taşıyıcı banttan alınan kül örneğinde saptanan toplam $\mathrm{Pb}, \mathrm{Ni}, \mathrm{Cd}$, $\mathrm{Fe}, \mathrm{Cu}, \mathrm{Zn}, \mathrm{Mn}$, ve S miktarları Çizelge 3'de verilmiştir. 
Pb: Toprak örneklerinin toplam Pb kapsamları en düşük $10.2 \mathrm{mgkg}^{-1}$ (2 no'lu ormanlık alan), en yüksek $95.8 \mathrm{mgkg}^{-1}$ ( 23 no'lu tarım alanı) olarak belirlenmiştir. Toprakta bulunan $\mathrm{Pb}$ miktarı ana kaya, iklimsel koşullar veya topoğrafik koşullara bağlı olarak çok değişken olabilir. Aktaş (1991), toprakta 2-200 mg kg-1 değerleri arasında Pb bulunduğunu belirtirken, Schwertman vd. (1982), podzol toprakların 30-100 mg kg${ }^{-1} \mathrm{~Pb}$ içerdiğini belirtmişlerdir. Aubert ve Pinta (1979) ise bir çalışmalarında, kirlenmemiş topraklarda $10-80 \mathrm{mg} \mathrm{kg}^{-1} \mathrm{~Pb}$ saptadıklarını, santral yakınlarındaki topraklarda da bu değerlere yakın değerler bulduklarını ve kıyaslama yapıldığında $\mathrm{Pb}$ birikiminin henüz olmadığını belirtmişlerdir. Haktanır vd. (1995), Ankara bölgesinde trafiğe yakın topraklarda $120 \mathrm{mgkg}^{-1} \mathrm{~Pb}$, trafikten uzak ve kirlenmemiş alanlardan alınan topraklarda ise $25 \mathrm{mgkg}^{-1} \mathrm{~Pb}$ belirlemişlerdir. $\mathrm{Bu}$ projede çalışma alanının, yani santral ve çevresinin kırsal alan olmasından dolayı santralden etkilenimin olmasına karşın $\mathrm{Pb}$ değerleri birkaç değer dışında kırsal alan değerleriyle benzerlik göstermektedir. Yatağan santralinden alınan kül $\mathrm{Pb}$ değeri $81.4 \mathrm{mgkg}^{-1}$, olarak saptanmıştır ki bu değer görüldüğü gibi düşük bir değerdir. Baba (2002), Yatağan Termik Santralinin 3 km'lik çevresinden aldığ 1 toprak örneklerinde KB yönünde örnekleme noktalarında $\mathrm{Pb}$ konsantrasyonunun arttığını, bunun nedeninin de geçmişte küllerin kuru sistemle depolanması ve bu depolanmanın KB hakim rüzgar yönünde olmasından kaynaklandığını belirtmiş̧ir. Çiçek ve Koparal (2004), Tunçbilek Santrali çevresinde yaptıkları çalışmada benzer sonuca varmışlardır.

Ni: Toplam Ni en düşük ve en yüksek olmak üzere sırasıyla $7.9 \mathrm{mgkg}^{-1}$ (12 no'lu) ve $51,6 \mathrm{mg}$ $\mathrm{kg}^{-1}$ olarak (13 no'lu) orman topraklarında saptanmıştır. 1,5,6 ve 8 no'lu örneklerde $40 \mathrm{mgkg}^{-1}$ in biraz üzerinde değerler saptanmıştır. Çiçek ve Koparal (2004) Tunçbilek Termik santrali çevresinde yaptıkları araştırmada toprakların Ni kapsamlarını $20.1-372 \mathrm{mgkg}^{-1}$ arasında bulmuşlar, kritik düzeyi $50 \mathrm{mgkg}^{-1}$ bildirmişlerdir. Daha yüksek değerler Seyitömer termik santrali çevresi topraklarında bulunmuştur. $\mathrm{Bu}$ yüksekliğin toprakların jeolojik yapısından kaynaklandığı yapılan bir çalışmayla ortaya konmuştur (Kadıŏlu ve Bayramin, 2007). Yatağan kül örneğinin Ni değeri $49.1 \mathrm{mgkg}^{-1}{ }^{\prime}$ dir, görüldüğü gibi bu değer yüksek bir değer değildir. Sonuçlar, Baba (2002) tarafindan yapılan araştırma sonuçları ile uyumlu bulunmuştur. Topraklar Ni içerikleri yönünden değerlendirildiğinde, G ve GB esintili rüzgarlar doğrultusunda kalan 13 no'lu örneğin $\mathrm{Ni}$ içeriği $50 \mathrm{mgkg}^{-1}$ civarında olup belirlenen en yüksek değeri oluşturmaktadır. Schwertman vd. (1982), Almanya topraklarının ortalama 10-50 $\mathrm{mgkg}^{-1} \mathrm{Ni}$ içerdiğini saptamışlardır. GAP bölgesi gibi endüstriyel bulaşmanın etkin olmadığ topraklarda 11.4-60.2 $\mathrm{mgkg}^{-1}$ arasında Ni bulunduğu belirtilmektedir (Hakerlerler vd. 1992).

Cd: Toprakların toplam Cd değerleri en düşük $6.45 \mathrm{mgkg}^{-1}$ (12 no'lu ormanlık alan) en yüksek $12.35 \mathrm{mgkg}^{-1}$ (20 no'lu tarım alanı) bulunmuştur. Çevre Bakanlığı Toprak Kirliliği Yönetmeliğine göre toprakların $\mathrm{Cd}$ için sınır değerleri $\mathrm{pH}<6$ için $1 \mathrm{mgkg}^{-1}, \mathrm{pH}>6$ için $3 \mathrm{mgkg}^{-1}$ olarak belirtilmiştir. Bölgede $\mathrm{Cd}$ dağılımı ilginç bir özellik göstermekte olup, tarım alanlarında $\mathrm{Cd}$ artışı dikkati çekmektedir. $6,20,22,23,25$ nolu örneklerin $\mathrm{Cd}$ içerikleri diğerlerine göre yüksek bulunmuştur. $\mathrm{Bu}$ alanların tarım alanları olması nedeniyle $\mathrm{Cd}$ yüksekliği gübre ve diğer tarımsal girdilerin kullanımından kaynaklanabilir. İlgililerle yapılan görüşmelerde son yıllarda yörede üretilen ballarda bulunan Cd miktarında artış olduğu belirtilmiştir (Muğla Tarım İl Müdürlüğü, Sözlü Görüşme 2002). En yüksek Cd içeriğinin saptandığı 20 no'lu örneğin, kül depolama alanına çok yakın olması geçmişte bu bölgeden esintilerle bu alana Cd içeriği yüksek kül partiküllerinin taşınma olasıllı̆ı olduğunu ve alanı etkilediğini düşündürmektedir. Yatağan kül örneğinin $12.95 \mathrm{mgkg}^{-1} \mathrm{Cd}_{\mathrm{kapsam}}$

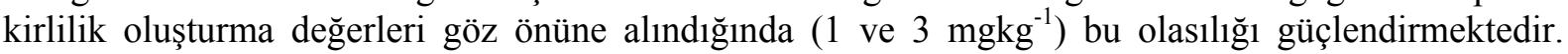
Çiçek ve Koparal (2004) Tunçbilek termik santrali çevresinde yaptıkları araştırmada topraklarda 1.4$21.7 \mathrm{mgkg}^{-1}$ arasında değişen Cd değerleri saptamışlardır.

Fe: Toprakların toplam Fe içerikleri ana materyale bağlı olarak \%0.02-10 arasında değişmekle beraber (Güneş vd. 2000), santralden itibaren hakim rüzgar yönünde ormanlık ve yüksek rakımlı alanlara gidildikçe Fe konsantrasyonunda önemli düzeyde bir artış gözlenmiştir. Bu durum bölgenin jeolojik yapısı ile ilgili olabilir (kalkerli yapı). Toplam Fe düzeyleri tarım toprağında en düşük (23) $5500 \mathrm{mgkg}^{-1}$, orman toprağında en yüksek (12) $40400 \mathrm{mgkg}^{-1}$ dır. Santralden alınan kül örneğinin 
toplam Fe kapsamı $10950 \mathrm{mgkg}^{-1}$ olarak bulunmuştur. Baba (2002) aynı bölgede yaptığı çalışmada toprak örneklerinin Fe içeriklerinin \%0.82-2.73 arasında değiştiğini belirlemiştir. Bu bulgulara karşın Nuhoğlu ve Bülbül (2003), Yatağan Termik santrali uçucu küllerinde yaptıkları araştırmada $\mathrm{Fe}$ kapsamını \% 7.24 olarak saptamışlardır.

Çizelge 3. Toprakların Toplam Ağır Metal kapsamları ile toplam S miktarları $\left(\mathrm{mgkg}^{-1}\right)$.

\begin{tabular}{|c|c|c|c|c|c|c|c|c|}
\hline $\begin{array}{l}\text { Örnek } \\
\text { no }\end{array}$ & $\mathrm{Pb}$ & $\mathrm{Ni}$ & $\mathrm{Cd}$ & $\mathrm{Fe}$ & $\mathrm{Cu}$ & $\mathrm{Zn}$ & $\mathrm{Mn}$ & S \\
\hline 1 & 54,7 & 42,2 & 9,15 & 16200 & 84,4 & 135 & 2185 & 98,78 \\
\hline 2 & 10,8 & 37,9 & 8,05 & 24200 & 29,7 & 52,2 & 657 & 95,73 \\
\hline 3 & 30,9 & 34,9 & 7,85 & 13600 & 39,1 & 56,3 & 1065 & 145,65 \\
\hline 4 & 36,3 & 30,7 & 7,55 & 15000 & 19,0 & 40,2 & 94 & 118,37 \\
\hline 5 & 30,1 & 41,9 & 8,55 & 14800 & 39,5 & 74,6 & 756 & 53,39 \\
\hline 6 & 40,5 & 42,2 & 11,5 & 11400 & 26,8 & 67,4 & 450 & 399,44 \\
\hline 7 & 64,3 & 32,7 & 7,65 & 17100 & 21,6 & 48,3 & 325 & 108,06 \\
\hline 8 & 46,3 & 40,2 & 10,6 & 12400 & 23,1 & 63,9 & 565 & 673,08 \\
\hline 9 & 13,8 & 20,1 & 7,35 & 13200 & 24,3 & 38,5 & 545 & 63,57 \\
\hline 10 & 23,4 & 23,1 & 7,75 & 12200 & 32,5 & 60,9 & 437 & 75,58 \\
\hline 11 & 35,1 & 26,9 & 8,15 & 17300 & 23,6 & 58,9 & 275 & 728,03 \\
\hline 12 & 24,2 & 7,9 & 6,45 & 40400 & 6,00 & 19,8 & 86 & 95,47 \\
\hline 13 & 73,3 & 51,6 & 8,95 & 21600 & 52,8 & 99,9 & 1668 & 113,39 \\
\hline 14 & 17,7 & 39,1 & \begin{tabular}{|l|}
7,05 \\
\end{tabular} & 23600 & 27,1 & 53,5 & 403 & 70,76 \\
\hline 15 & 64,7 & 35,5 & 7,15 & 17800 & 30,6 & 51,8 & 563 & 101,29 \\
\hline 16 & 41,5 & 24,8 & 7,45 & 10200 & 23,4 & 42,0 & 467 & 213,15 \\
\hline 17 & 72,8 & 29,5 & 7,35 & 14000 & 23,8 & 48,2 & 561 & 102,51 \\
\hline 18 & 40,1 & 30,8 & 6,75 & 7500 & 19,0 & 31,4 & 382 & 151,89 \\
\hline 19 & 81,2 & 21,0 & 8,05 & 8900 & 18,7 & 39,8 & 499 & 488,35 \\
\hline 20 & 94,9 & 29,3 & 12,4 & 7100 & 16,1 & 43,5 & 260 & 486,46 \\
\hline 21 & 10,2 & 28,5 & 8,65 & 8000 & 10,9 & 34,2 & 330 & 275,01 \\
\hline 22 & 79,3 & 29,1 & 10,8 & 6000 & 11,8 & 36,9 & 190 & 276,31 \\
\hline 23 & 95,8 & 27,9 & 11,2 & 5500 & 9,50 & 23,1 & 147 & 296,76 \\
\hline 24 & 66,4 & 35,9 & 9,85 & 18800 & 41,1 & 59,0 & 531 & 447,66 \\
\hline 25 & 82,4 & 23,0 & 11,0 & 8900 & 20,7 & 45,2 & 232 & 298,65 \\
\hline 26 & 35,1 & 28,4 & 8,55 & 18300 & 17,7 & 34,5 & 312 & 108,46 \\
\hline 27 & 63,4 & 16,3 & 6,65 & 11100 & 10,4 & 30,4 & 175 & 138,49 \\
\hline Kül & 81,4 & 49,1 & 12,95 & 10950 & 37,0 & 63,55 & 281 & 31335,5 \\
\hline
\end{tabular}

Cu: Alınan örneklerden 1 no'lu zeytinlik $\left(84,4 \mathrm{mgkg}^{-1}\right)$ ile 13 no'lu orman (52.8 ppm) ve 24 no'lu tarım alanı (41.1 mgkg ${ }^{-1}$ ) hariç genelde toprakların $\mathrm{Cu}$ değerleri $6.0-39.5 \mathrm{mgkg}^{-1}$ arasında bulunmuştur. En düşük değer orman içi tarım alanında $6.00 \mathrm{mgkg}^{-1}$ dır. Aynı santral çevresinde daha dar bir alanda çalışan Baba (2003), topraklarda $\mathrm{Cu}$ değerlerinin 10-26 $\mathrm{mgkg}^{-1}$ arasında değiştiğini, uçucu küllerde ve kül depolama alanından alınan örneklerde $\mathrm{Cu}$ miktarlarının topraklardan daha yüksek olduğunu belirtmiştir. Kül örneği Cu kapsam1 $37.0 \mathrm{mgkg}^{-1}$ bulunmuştur. Diğer yandan Çiçek ve Koparal (2004) Tunçbilek termik santrali çevresinde yaptıkları araştırmada toprakların $\mathrm{Cu}$ 
kapsamlarının 12.6-261.3 $\mathrm{mgkg}^{-1}$ arasında değiştiğini saptamışlar ve kritik seviyenin $50-125 \mathrm{mgkg}^{-1}$ arasında olduğunu belirtmişlerdir. Zeytinlik olan 1 no'lu toprağın $\mathrm{pH}$ değerinin asidik olması ve santrale yakın olması buradaki $\mathrm{Cu}$ yoğunlaşmasının sebepleri olarak belirtilebilir.

Zn: Araştırma bölgesinin $\mathrm{Zn}$ dağılımına bakıldığında, santrale en yakın mesafede ancak yamaç bir arazide yer alan 1 no'lu zeytinlik toprağında saptanan $\mathrm{Zn}$ değerinin $\left(135 \mathrm{mgkg}^{-1}\right)$ diğer örneklerin Zn kapsamlarından birkaç kat daha fazla yüksek değeri göstermesi dikkat çekicidir. Toprak örneklerinde ve külde bulunan Zn değerleri Baba (2003)'nın sonuçları ile uyumludur. Aubert ve Pinta (1977) genelde toprakların $\mathrm{Zn}$ değerlerinin $50-100 \mathrm{mgkg}^{-1}$ arasında değiştiğini, Kloke (1980) ise $\mathrm{Zn}$ kirliliğinin topraklarda sınır değerinin $250 \mathrm{mgkg}^{-1}$ olduğunu bildirmişlerdir. Toprak Kirliliği Kontrol Yönetmeliğinde de $\mathrm{Zn}$ için belirtilen sınır değerler; $\mathrm{pH}<6$ olan topraklarda $150 \mathrm{ppm}, \mathrm{pH}>6$ olan topraklarda ise $\mathrm{Zn} 300 \mathrm{mg} \mathrm{kg}^{-1}$ dır. Bu yörede üretim yapan çiftçilerle yapılan görüşmelerde zeytin yapraklarında sık sık uç yanmalarının gözlendiği ifade edilmiştir. Benzer gözlem tarafımızdan da yapılmıştır. Bu gözlemler emisyonların bu bölgeye taşındığını göstermekte ise de toprakta saptanan değerlerin sınır değerler civarında olduğu göz önünde bulundurulursa yukarıda da belirtildiği gibi henüz toprakta bir Zn kontaminasyonundan bahsetmek olası değildir. Diğer yandan kül örneğinin Zn değerine $\left(63.55 \mathrm{mgkg}^{-1}\right)$ bakıldığında $\mathrm{Zn}$ yönünden kül depolama alanları ve çevresinde zamanla birikim olacağ 1 düşünülebilir.

Mn: Yüksek toplam Mn değerleri 1 no'lu zeytinlik (2185 $\left.\mathrm{mgkg}^{-1}\right), 3$ no'lu orman (1065 mgkg$\left.{ }^{1}\right)$ ve 13 no'lu orman (1668 $\left.\mathrm{mgkg}^{-1}\right)$ örneklerinde belirlenmiştir. Baba (2003) aynı alanda toprak örnekleri için toplam $\mathrm{Mn}$ değerlerinin 103-683 $\mathrm{mgkg}^{-1}$ arasında değiştiğini saptamıştır. Baba (2003)'nın Yatağan santraline 1-2 km uzaklıkta saptamış olduğu toplam Mn değerleri ile bu araştırmada aynı mesafede kalan örneklerin $\mathrm{Mn}$ değerleri benzerlik göstermektedir. Hakim rüzgar yönünde ve santrale 4.5-7.5 km mesafelerde yüksek ormanlık arazilerde daha yüksek Mn değerleri saptanmıştır. Aubert ve Pinta (1977), çoğu toprakların toplam Mn değerlerinin $500-1000 \mathrm{mgkg}^{-1}$ arasında değiştiğini belirtmişlerdir. Topraklarda ana materyal dışında Mn kaynağı gübrelerdir. Ancak Mn kapsamı yüksek alanlar içinde ormanların bulunması Mn girdisinin tamamen gübrelerden kaynaklanmadığını göstermektedir. Bu alanların hâkim rüzgar yönünde, geçmişte orman serilerinde zararlanmaların çok olduğu bölgede yer alması dikkat çekicidir. Külde saptanan ortalama değer 281 $\mathrm{mgkg}^{-1}$ 'dir. Bu değer Baba (2003)'ün kül sonuçları ile uyumludur.

S: Ilıman bölge topraklarında toplam S içeriği $50-400 \mathrm{mgkg}^{-1}$ arasında değişmektedir (Aktaş 1995). Bu araştırmada toprak örneklerinde saptanan $S$ değerleri en düşük $53.39 \mathrm{mgkg}^{-1}$, en yüksek $728.03 \mathrm{mgkg}^{-1}$ dır. Saptanan yüksek $\mathrm{S}$ değerlerinin hakim rüzgar yönüne bağlı olarak etkilendiği belirlenmiştir. Kükürt miktarı ormanlık alan olan 11 no'lu örnekte $728, .03 \mathrm{mgkg}^{-1}$ ve bunu izleyen 8 no'lu ormanlık alanda $673.08 \mathrm{mgkg}^{-1}$ olarak saptanmıştır. 19,20 ve 24 no'lu tarım alanlarında ise değerler sırasıyla $488.34,486.47$ ve $447.66 \mathrm{mgkg}^{-1}$ olarak belirlenmiştir. Kül örneğinde ise S miktarı çok yüksek olup 31335,55 $\mathrm{mgkg}^{-1}$ (yaklaş1k \%3,1) bulunmuştur. Bu değer kömürde bulunan değerler (\%1.9-4.3) arasındadır. Kömürlerin kimyasal bileşimleri çıkarıldıkları yatakların damarlarına göre bile değişim göstermektedir (Baba 2006, sözlü görüşme). Bu nedenle yüksek değerler bulunması olasıdır. Moen vd. (1986), Hollanda'da çıkarılan "Toprak Koruma” kanununda toplam S'e ilişkin 3 ayrı başlangıç değerinin olduğunu bildirmişlerdir: toplam S miktarı $2 \mathrm{mgkg}^{-1}$ olan topraklar "kirletilmemiş" topraklar, $20 \mathrm{mgkg}^{-1} \mathrm{~S}$ içeren topraklar olası bir bulaşma tehlikesine karşı araştırma yapılması gerekli olan topraklar, $200 \mathrm{mgkg}^{-1}$ ' 1 üstünde $\mathrm{S}$ içerenler ise temizlenmesi zorunlu olan topraklardır. Her ne kadar ülkelerin toprak ve iklim yapıları farklılık gösterse de bu değerlere bakılacak olursa S yönünden önemli bir sorun olduğu görülebilir. Karaca (1997), Afşin-Elbistan termik santrali baca gazı emisyonlarının toprakların toplam $S$ dağılımı üzerine yaptığı araştırmada, özellikle santrale $2 \mathrm{~km}$ mesafeye kadar ve $30 \mathrm{~km}$ 'deki örneklerde önemli S birikimlerinin olduğunu ve derinliğe bağlı olarak $\mathrm{S}$ miktarının azaldığını ve toprak yüzeyindeki birikmenin belirgin olduğunu belirtmiştir.

Kerme Körfezi'nin kuzeyinde yer alan Yatağan'da kurulmuş olan termik santralinin baca gazları, yörede kuzey rüzgarları etkisinde bulunan Bencik Dağı ile Sepetçi Dağg üzerinde bulunan 
kızılçam ormanlarının ve çevredeki tarım alanlarının şiddetle etkilenmesine neden olmuştur. Bencik Dağ1 - Sepetçi Dağı arazisinde henüz kurumamış olan kızılçam ormanlarında ise önemli bir artım düşüklüğü belirlenmiştir. Bu ormanlardaki kızılçamların yapraklarında $\mathrm{S}$ oranı $1,600-3,800 \mathrm{mgkg}^{-1}$ arasında olup, yıllık halkaları çok daralmıştır. $\mathrm{Bu}$ şekilde etkilenmiş olan kızılçam ağaçlarının kerestelik odun kalitesinde de önemli ve olumsuz değişiklikler olmaktadır. Asit yağmurlarından etkilenen toprakların reaksiyonunun yer yer 4.3 PH'ya $\left(0.1 \mathrm{~N} \mathrm{KCl}^{\prime}\right.$ de) düştüğü bildirilmiştir. $\mathrm{Bu}$ durum ağaçların beslenmesini etkileyen ve kurumalarını kolaylaştıran bir faktördür. Ayrıca çevredeki köylerde; zeytin, antep fistığı, incir, badem ağaçları, üzüm bağları, sebzecilik ve yaygın tarım ürünü olan tütüncülük şiddetle zarar görmüştür. Ağaçların bir kısmı kurumuş, kurumayanların verimi \%6080 oranında azalmıştır (Türk Tabipleri Birliği, 2000).

\subsection{Araştırma Topraklarının Ekstrakte edilebilir $\mathrm{Pb}, \mathrm{Ni}, \mathrm{Cd}, \mathrm{Fe}, \mathrm{Cu}, \mathrm{Zn}, \mathrm{Mn}$ ve S Kapsamları}

Araştırma topraklarının DTPA ile ekstrakte edilebilir ağır metal ve alınabilir kükürt kapsamları Çizelge 4'de verilmiştir.

Pb: Ekstrakte edilebilir $\mathrm{Pb}$ değerleri en düşük 0.09 ve en yüksek $1.04 \mathrm{mgkg}^{-1}$ dır. En yüksek değerin 6 no'lu orman içinde tarım alanında ortaya çıktığı görülmektedir. Bu örnek hakim rüzgar doğrultusundan oldukça uzakta yer alan bir örnektir. Hakim rüzgar doğrultusunda bunu takip eden ikinci yüksek değer 8 no'lu (orman- $0.86 \mathrm{mg} \mathrm{kg}^{-1}$ ) örnekte görülmektedir. Bu değerler oldukça düşüktür, bölgede tarım açısından $\mathrm{Pb}$ kirlenmesi ile ilgili henüz endişe edici bir durum olmadığı düşünülmektedir. Kül örneklerinin ortalama ekstrakte edilebilir $\mathrm{Pb}$ miktarı $11.85 \mathrm{mg} \mathrm{kg}^{-1}$ olarak bulunmuştur.

Ni: Örnekler içinde en yüksek Ni değerleri 1nolu zeytinlik, 3 no'lu orman,11 no'lu orman ve 14 no'lu orman içinde tarım alanında saptanmıştır. Toprak örneklerinin ekstrakte edilebilir Ni kapsamları en düşük $0,24 \mathrm{mgkg}^{-1}$, en yüksek $1.65 \mathrm{mgkg}^{-1}$ dır. Ekstrakte edilebilir Ni kapsamının pH'nın düşmesine bağlı olarak arttı̆g 1 ve kil mineralleri, organik madde ile $\mathrm{Mn}$ ve $\mathrm{Fe}$ oksitlerin miktarındaki artışa bağlı olarak azaldığı bildirilmektedir (Özbek vd. 1993).

Cd: Ekstrakte edilebilir Cd değeri yine diğer elementlerde olduğu gibi en yüksek 1 no'lu toprak (zeytinlik) örneğinde saptanmıştır. 13 (orman) ve 11 (orman) no'lu örneklerde de diğer örneklere nazaran daha yüksek değerler belirlenmiştir. Araştırma topraklarının ekstrakte edilebilir $\mathrm{Cd}$ içerikleri 0,02 ile $0.43 \mathrm{mg} \mathrm{kg}^{-1}$ arasındadır. Alloway (1968), toprak çözeltisindeki $0.001 \mathrm{mgkg}^{-1}$ düzeyindeki Cd'u sınır değer olarak belirtmiştir. Dolayısıyla örneklerin ekstrakte edilebilir Cd kapsamları sınır değerin üstündedir ve Cd bulaşmasının ilerlemiş olduğu anlaşılmaktadır. Santralden alınan kül örneklerinin ise ortalama ekstrakte edilebilir $\mathrm{Cd}$ miktarı $0.10 \mathrm{mg} \mathrm{kg}^{-1}$ dır. Ekstrakte edilebilir Cd miktarına, toprakların toplam $\mathrm{Cd}$ içeriği ve toprak pH'sı önemli düzeyde etki etmektedir. Artan pH'ya bağlı olarak $\mathrm{Cd}$ adsorpsiyonu artmakta ve Cd'nin çözünürlüğü azalmaktadır. Cd konsantrasyonu toprak çözeltisinde $\mathrm{pH}$ 7'de en düşük düzeyde, $\mathrm{pH}$ 6-6.5 değerinin altında ise konsantrasyonu hızla yükselmektedir. Ayrıca Cd'un büyük kısmının topraklarda adsorbe olmuş formda bulunması nedeniyle, Cd'un çözünülürlüğü toplam Cd artışına bağlı olarak artmaktadır (Özbek vd. 1993).

Fe: Hâkim rüzgar doğrultusunda yer almakta olan 8 (orman), 11 (orman), 12 (orman) 14 ve 27 no'lu (orman içinde tarım alanı) örneklerin Fe kapsamları aynı yöndeki diğer örneklere kıyasla daha yüksektir. Toprakların ekstrakte edilebilir demir içerikleri birbirinden oldukça farklılık göstermektedir. En düşük ekstrakte edilebilir Fe içeriği $1,78 \mathrm{mgkg}^{-1}$, en yüksek değer $45,1 \mathrm{mgkg}^{-1}$, dır. Kuzey batı yönlü hakim rüzgar istikametinde ters yönünde alınmış 21-26 (tarım alanları ve zeytinlikler) no'lu örneklerin ekstrakte edilebilir Fe miktarları ise 3.48-6.48 $\mathrm{mgkg}^{-1}$ arasında değişmiştir. Karaca (1997), Afşin-Elbistan termik santrali baca gazı emisyonlarının çevre topraklarına etkisini incelediği çalışmasında santralden uzaklaştıkça toprakların ekstrakte edilebilir $\mathrm{Fe}$ kapsamlarının artış gösterdiğini bildirmiştir. 
Çizelge 4. Toprakların DTPA ile ekstrakte edilebilir ağır metal kapsamları $\left(\mathrm{mgkg}^{-1}\right)$.

\begin{tabular}{|l|l|l|l|l|l|l|l|l|}
\hline $\begin{array}{l}\text { Örnek } \\
\text { No. }\end{array}$ & $\mathrm{Pb}$ & $\mathrm{Ni}$ & $\mathrm{Cd}$ & $\mathrm{Fe}$ & $\mathrm{Cu}$ & $\mathrm{Zn}$ & $\mathrm{Mn}$ & $\mathrm{S}$ \\
\hline 1 & 0,29 & 1,30 & 0,43 & 9,62 & 2,94 & 1,82 & 48,0 & 11,6 \\
\hline 2 & 0,69 & 0,41 & 0,03 & 7,50 & 0,22 & 0,16 & 7,62 & 9,90 \\
\hline 3 & 0,35 & 1,36 & 0,15 & 14,7 & 1,00 & 0,62 & 19,7 & 8,50 \\
\hline 4 & 0,39 & 0,41 & 0,04 & 4,90 & 0,96 & 0,18 & 1,54 & 4,95 \\
\hline 5 & 0,43 & 0,25 & 0,06 & 1,78 & 0,22 & 0,16 & 1,70 & 8,25 \\
\hline 6 & 1,04 & 0,58 & 0,11 & 2,36 & 1,20 & 0,58 & 2,00 & 6,60 \\
\hline 7 & 0,22 & 0,31 & 0,03 & 6,32 & 0,70 & 0,46 & 6,80 & 11,5 \\
\hline 8 & 0,86 & 0,56 & 0,39 & 21,1 & 0,52 & 2,50 & 6,02 & 21,5 \\
\hline 9 & 0,14 & 0,45 & 0,05 & 7,04 & 0,38 & 0,28 & 27,2 & 9,90 \\
\hline 10 & 0,12 & 0,27 & 0,06 & 5,48 & 1,06 & 0,44 & 10,0 & 13,2 \\
\hline 11 & 0,50 & 1,47 & 0,20 & 45,1 & 0,56 & 3,26 & 16,6 & 24,8 \\
\hline 12 & 0,35 & 0,37 & 0,02 & 21,1 & 0,10 & 0,20 & 4,52 & 9,00 \\
\hline 13 & 0,18 & 0,69 & 0,22 & 11,7 & 0,62 & 0,44 & 15,3 & 13,0 \\
\hline 14 & 0,32 & 1,65 & 0,04 & 26,8 & 0,44 & 0,38 & 34,4 & 9,00 \\
\hline 15 & 0,09 & 0,24 & 0,02 & 5,78 & 0,22 & 0,16 & 4,92 & 13,0 \\
\hline 16 & 0,42 & 0,61 & 0,10 & 5,98 & 1,80 & 0,36 & 8,68 & 9,50 \\
\hline 17 & 0,24 & 0,42 & 0,05 & 3,16 & 1,34 & 0,48 & 8,64 & 19,8 \\
\hline 18 & 0,13 & 0,66 & 0,04 & 4,96 & 0,58 & 0,40 & 11,4 & 47,9 \\
\hline 19 & 0,39 & 0,56 & 0,09 & 5,04 & 1,24 & 0,60 & 8,20 & 5,00 \\
\hline 20 & 0,53 & 0,74 & 0,10 & 4,48 & 0,78 & 1,46 & 7,62 & 14,9 \\
\hline 21 & 0,57 & 0,61 & 0,07 & 3,48 & 0,60 & 0,40 & 4,90 & 6,50 \\
\hline 22 & 0,41 & 0,75 & 0,07 & 4,42 & 0,62 & 0,54 & 5,54 & 9,25 \\
\hline 23 & 0,39 & 0,65 & 0,03 & 3,56 & 0,24 & 0,22 & 5,22 & 8,50 \\
\hline 24 & 0,49 & 0,62 & 0,09 & 6,48 & 1,72 & 1,22 & 11,6 & 6,50 \\
\hline 25 & 0,40 & 0,63 & 0,03 & 4,70 & 1,94 & 1,54 & 8,10 & 4,95 \\
\hline 26 & 0,44 & 0,44 & 0,02 & 4,68 & 0,64 & 0,26 & 4,66 & 13,2 \\
\hline 27 & 0,11 & 0,52 & 0,02 & 20,9 & 0,16 & 0,22 & 9,62 & 11,5 \\
\hline $\mathrm{kül}$ & 0,62 & 0,69 & 0,10 & 11,85 & 0,68 & 0,26 & 0,03 & - \\
\hline
\end{tabular}

Cu: Toprakların ekstrakte edilebilir $\mathrm{Cu}$ kapsamı yönünden yine 1 no'lu zeytinlik toprağı en yüksek $\mathrm{Cu}$ değeri göstermiștir. Bunu tarım alanları olan 25, 16, 24 ve 17 nolu örnekler izlemiştir. Bakır en düşük $0,10 \mathrm{mgkg}^{-1}$ en yüksek $2,93 \mathrm{mgkg}^{-1}$, ortalama $0.84 \mathrm{mgkg}^{-1}$ olarak saptanmıştır. Külün ortalama Cu kapsamı $0.68 \mathrm{mgkg}^{-}$dır. Dhane ve Shukla (1995) yüzey topraklarında ekstrakte edilebilir $\mathrm{Cu}$ ile organik madde kapsamının çok önemli pozitif ilişki içerisinde bulunduğunu saptamışlardır.

Zn: En yüksek değere sahip 11 nolu orman örneğini, 8 (orman), 1 (zeytinlik), 25 (tarım alanı), 20 (tarım alanı), 24 (tarım alanı) nolu toprak örnekleri izlemiş ve değerler $3.26-1.22 \mathrm{mg} \mathrm{kg}^{-1}$ arasında değişim göstermiştir. Ekstrakte edilebilir $\mathrm{Zn}$ içerikleri en düşük $0,16 \mathrm{mg} \mathrm{kg}^{-1}$ en yüksek $3,26 \mathrm{mgkg}^{-}$ ${ }^{1}$ 'dir. Udo vd. (1970), kireçli alkalin topraklarda çinkonun, toprak kompleksleri ile güç çözünen bileşikleri oluş̧urduğunu ve böylece yarayışlılığın azaldığını bildirmektedir.

Mn: En yüksek Mn yine 1 no'lu (zeytinlik) örnekte belirlenmiş olup, 14 (orman içinde tarım alanı), 9 (orman), 3 (orman), ve 13 (orman) no'lu örneklerde de diğer örneklere göre daha fazla Mn saptanmıştır. Toprakların ekstrakte edilebilir Mn kapsamları en düşük $1.54 \mathrm{mgkg}^{-1}$, en yüksek 48 $\mathrm{mgkg}^{-1}{ }^{\prime} \mathrm{d}_{1}$ ' Bu toprak örneklerinin pH'ları irdelendiğinde asidik oldukları (4.83-5.43) görülmektedir. Asit $\mathrm{pH} 1_{1}$ topraklarda Mn bileşiklerinin çözünürlüğü yüksektir. Küldeki ortalama Mn miktarı oldukça düşük olup $0.03 \mathrm{mgkg}^{-1}$ dır. 
S: En yüksek değeri 18 no'lu tarım alanı göstermiştir. Araştırma topraklarının ekstrakte edilebilir S kapsamlarının 4,95 ile 47,9 $\mathrm{mgkg}^{-1}$ arasında değiştiği, ortalama $12.3 \mathrm{mgkg}^{-1}$ saptanmıştır. Türkiye topraklarının ekstrakte edilebilir $\mathrm{S}$ içeriklerinin belirlenmesi amacıyla yürütülen bir çalışmada, Türkiye topraklarının \% 11.5'inin kritik düzey olarak belirlenen $10 \mathrm{mgkg}^{-1} \mathrm{~S}^{\prime}$ ün altında olduğunu belirtilmiştir (Ülgen vd., 1989).

\subsection{Bitki Örneklerinin Toplam Pb, Ni, Cd, Fe, Cu, Zn, Mn ve S İçerikleri}

Toprak örneklerinin alınması sırasında, tarımı yapılan kültür bitkileri ve orman vejetasyonu örneklerinden de tesadüfî örnekleme yapılmıştır. Bitki çeşitlerine göre ağır metal ve kükürt içerikleri Çizelge 5'de verilmiştir. Bitki türlerinin çeşitliliğgi nedeniyle sonuçlar geniş bir dağılım göstermektedir. Bitkilerin çeşitli faaliyetler sonucu ekolojik sisteme girmiş olan ağır metalleri bünyelerine aldıkları hatta biriktirdikleri bilinmektedir. Toprakların elementlerce varsıl veya yoksul oluşu ise oluşum koşulları, oluştukları ana materyal, iklim, topoğrafya gibi koşullara bağlı olarak değişiklik göstermektedir. Bitkiler asıl olarak toprakta bulunan elementleri kökleri vasıtasıyla absorbe etmekle birlikte Bryophytes (kara yosunları) gibi atmosferik taşınım ile gelen elementleri de bünyelerine alabilirler. Bu özellikten dolayı hava kaynaklı ağır metallerin izlenmesinde bazı bitkiler, likenler ve yosunlar anatomik, fizyolojik (yüksek adsorpsiyon kapasitesi gibi) ve morfolojik karakterlerinden dolayı biyolojik monitör olarak kullanılmaktadır. Bitki yaprak yüzeyi özellikleri atmosferik kontaminasyon nedeniyle ulaşan ağır metallerin tutulmasında farklı etkiler oluşturabilmektedir; örneğin yaprak yüzeyi tüylü olan bitkilerin tüylü olmayanlara göre daha fazla $\mathrm{Pb}$ tuttuğu belirlenmiştir (Martin ve Coughtrey, 1982). Yine bitkilerin yapraklarının yaşları da önem taşımaktadır, 2 yıllık çam ibrelerinin 1 yıllık ibrelere göre daha fazla metal içerdiği ortaya konmuştur (Ward vd., 1974).

Pb: Bitki örneklerinin $\mathrm{Pb}$ kapsamları 0.27-10.58 $\mathrm{mgkg}^{-1}$ arasında değişmiştir. En yüksek değer kara yosununda saptanmış olup $10.58 \mathrm{mgkg}^{-1}$ dir. Uğur vd. (2004) aynı çalışma alanında yaptıkları araștırmada santrale $3 \mathrm{~km}$ uzaklıktan alınan karayosununda Pb miktarını $47.23 \mathrm{ugg}^{-1}, 4.5 \mathrm{~km}$ uzaklıkta 45 ugg $^{-1}, 7 \mathrm{~km}$ uzaklıkta ancak farklı yönde alınan 2 ayrı örnekte $5.38 \mathrm{ugg}^{-1}$ ve 39.4 ugg $^{-1}$ olarak saptamışlardır. Kontaminasyonun olmadığı varsayılan noktada (50 km uzaklık) yapılan karayosunu örneklemesinde ise $23.96 \mathrm{ugg}^{-1} \mathrm{~Pb}$ belirlenmiştir.

$\mathrm{Bu}$ araştırmada farklı yerlerden alınan anız örneklerinde $\mathrm{Pb}$ değerleri 1.48 ile $6.85 \mathrm{mgkg}^{-1}$ arasında değişmiştir. Zeytin yapraklarında 0.27 ile $6.97 \mathrm{mgkg}^{-1}$, ormanlık alandan toplanan iğne yapraklı ağaçlarda ise en yüksek değer $7.64 \mathrm{mg} \mathrm{kg}^{-1}$ olarak saptanmıştır. Bu araştırmada özellikle doğal vejetasyon olarak bölgede yayılım gösteren karayosunu türlerinde en yüksek $\mathrm{Pb}$ değerinin bulunması ilgi çekicidir. Diğer yandan alınan örnekler içinde havuç ve susamın Pb kapsamlarına bakıldığında yenmesine izin verilebilir $\mathrm{Pb}$ değeri olan $0.5 \mathrm{mgkg}^{-1}$, den çok yüksektir (Bergmann 1992). Havucun kömür sularından gelen sularla yıkandığı göz önüne alınırsa bu suyun sulama için elverişli olmadığı açıtır.

Ni: Bitki örneklerinin Ni içerikleri $0,60-15,7 \mathrm{mg} \mathrm{kg}^{-1}$ arasında değişmiştir. En yüksek değer kara yosununda saptanmıştır $\left(15.7 \mathrm{mgkg}^{-1}\right)$. Bazı kaynaklarda belirtilen $25-40 \mathrm{mg} \mathrm{kg}^{-1}$ sınır değerlere göre (Çiçek ve Koparal, 2004) bu çalışmadaki bitki örneklerinin toplam Ni değerleri kritik düzeylerin altında olduğu görülmektedir. Bir çalışmada, Yatağan santraline $3 \mathrm{~km}, 4.5 \mathrm{~km}$ ve 7'şer km (iki ayrı nokta) uzaklıkta bulunan yerlerden alınan karayosunlarının Ni kapsamlarını sırasıyla 23.75, 18.3, 36.6, $25.27 \mathrm{ug} \mathrm{g}^{-1}$ olarak belirlenmiş ve bu değerlerin veritabanı değeri olarak alınan uzak bir noktadan (50 $\mathrm{km})$ alınan karayosunu değerinden (11,92 $\mathrm{ug} \mathrm{g}^{-1}$ ) daha yüksek olduğu belirtilmektedir (Uğur vd., 2004). 
Çizelge 5. Bitkilerin ağır metal $\left(\mathrm{mgkg}^{-1}\right)$ ve kükürt (\%) içerikleri

\begin{tabular}{|c|c|c|c|c|c|c|c|c|c|}
\hline Örnek no & Bitki Çeşidi & $\mathrm{Pb}$ & $\mathrm{Ni}$ & $\mathrm{Cd}$ & $\mathrm{Fe}$ & $\mathrm{Cu}$ & $\mathrm{Zn}$ & $\mathrm{Mn}$ & $\mathrm{S}$ \\
\hline 1 & Zeytin yaprağ 1 & 3,01 & 3,10 & 6,7 & 75,2 & 4,3 & 7 & 74,5 & 955 \\
\hline 2 & İğne yaprak & 1,13 & 2,10 & 2,5 & 50.1 & 2,3 & 29,8 & 33,4 & 1527 \\
\hline $3 / 1$ & İncir yaprağ1 & 4,51 & 4,30 & 2,2 & 67,6 & 2,7 & 5,7 & 106,5 & 1172 \\
\hline $3 / 2$ & İğne yaprak & 6,09 & 0,60 & 4,2 & 95,3 & 3,2 & 5,5 & 16,2 & 1154 \\
\hline 4 & Buğday anızı & 1,48 & 3,00 & 2,3 & 454,9 & 2,6 & 3,1 & 10,8 & 696 \\
\hline 5 & Misır anız1 & 2,80 & 12,5 & 3,0 & 123,3 & 7,3 & 40,1 & 19,7 & 916 \\
\hline $6 / 1$ & İğne yaprak & 7,08 & 2,00 & 2,5 & 81 & 2,0 & 16,7 & 41,2 & 1555 \\
\hline $6 / 2$ & Tütün yaprağ 1 & 4,05 & 3,90 & 5,4 & 138,8 & 8,0 & 3,7 & 36,5 & 2440 \\
\hline $7 / 1$ & Buğday anızı & 1,77 & 4,80 & 2,8 & 670,1 & 3,7 & 5,4 & 8,5 & 367 \\
\hline $7 / 2$ & Zeytin yaprağ 1 & 0,27 & 1,60 & 3,4 & 70,6 & 5,0 & 5,2 & 9,6 & 1131 \\
\hline $7 / 3$ & İğne yaprak & 5,82 & 1,50 & 3,5 & 47,2 & 3,1 & 8,3 & 9,4 & 961 \\
\hline $8 / 1$ & İğne yaprak & 3,55 & 0,70 & 3,6 & 50,2 & 1,8 & 56,9 & 180,4 & 1587 \\
\hline $8 / 2$ & Kara yosunu & 10,6 & 15,7 & 5,4 & 5500 & 15,6 & 11,4 & 250 & 2330 \\
\hline $9 / 1$ & İğne yaprak & 3,19 & 2,50 & 3,7 & 61,2 & 2,2 & 10,7 & 76,0 & 1876 \\
\hline $9 / 2$ & Piren bitkisi çiçeği & 5,72 & 2,80 & 3,2 & 72,4 & 6,1 & 43,5 & 38,0 & 821 \\
\hline 10 & Misir anız1 & 5,30 & 2,00 & 3,9 & 105 & 7,6 & 2,6 & 46,1 & 1259 \\
\hline $11 / 1$ & İğne yaprak & 5,03 & 1,90 & 3,7 & 63,9 & 2,7 & 6,7 & 176 & 1309 \\
\hline $11 / 2$ & Pırnal meşesi yaprağ1 & 3,94 & 4,10 & 3,9 & 79,4 & 5,6 & 8,3 & 109,2 & 761 \\
\hline 12 & İğne yaprak & 3,62 & 2,10 & 4,7 & 49,9 & 3,4 & 4,7 & 43,9 & 1595 \\
\hline $13 / 1$ & Pırnal meşesi yaprağı & 6,14 & 2,70 & 4,3 & 61,9 & 4,0 & 10,0 & 81,1 & 749 \\
\hline $13 / 2$ & $\dot{\text { İğne yaprak }}$ & 2,53 & 4,40 & 4,7 & 67,8 & 2,8 & 11,3 & 63,4 & 1323 \\
\hline 14 & Buğday anızı & 4,92 & 6,30 & 3,6 & 1056 & 3,9 & 4,7 & 470 & 507 \\
\hline 15 & Pırnal meşesi yaprağ1 & 9,31 & 5,60 & 4,6 & 59,4 & 3,5 & 1,9 & 27,9 & 719 \\
\hline $16 / 1$ & Buğday anızı & 6,85 & 2,60 & 4,00 & 375,6 & 3,30 & 17,3 & 72,7 & 287 \\
\hline $16 / 2$ & Yabani ot (piyam) & 2,34 & 3,00 & 4,70 & 179,3 & 6,20 & 6,50 & 14,0 & 1856 \\
\hline $16 / 3$ & Zeytin yaprağ 1 & 6,03 & 2,50 & 4,20 & 60,8 & 5,20 & 21,3 & 47,3 & 1047 \\
\hline $16 / 4$ & Pamuk yaprağ & 6,24 & 4,20 & 6,40 & 45,9 & 6,00 & 4,40 & 23,2 & 9391 \\
\hline $18 / 1$ & Misır üst yaprak & 5,61 & 3,00 & 3,90 & 86,7 & 6,10 & 7,30 & 48,1 & 1931 \\
\hline $18 / 2$ & Misir alt yaprak & 2,98 & 4,20 & 4,90 & 344,1 & 7,40 & 8,20 & 40,8 & 2208 \\
\hline $19 / 1$ & Havuç üst yaprak & 7,12 & 4,00 & 5,10 & 213,1 & 6,00 & 12,2 & 11,7 & 4011 \\
\hline $19 / 2$ & Havuç & 0,88 & 3,60 & 4,80 & 131,1 & 6,30 & 21,9 & 54,7 & 145 \\
\hline $20 / 1$ & Sirken yaprağ1 & 3,99 & 3,10 & 5,40 & 100,9 & 7,30 & 15,2 & 19,0 & 311 \\
\hline $20 / 2$ & Sirken kök & 6,68 & 2,80 & 5,00 & 242,1 & 6,30 & 13,6 & 2,30 & 645 \\
\hline 21 & Susam tane & 8,06 & 3,80 & 5,00 & 94,2 & 9,00 & 10,3 & 0,70 & 248 \\
\hline 22 & Zeytin yaprağ1 & 3,15 & 3,40 & 4,80 & 121,4 & 5,60 & 1,20 & 7,90 & 2131 \\
\hline 23 & Buğday anızı & 7,62 & 4,70 & 4,30 & 202,1 & 1,90 & 3,90 & 14,7 & 547 \\
\hline 24 & Zeytin yaprağ 1 & 5,63 & 1,50 & 5,90 & 86,2 & 3,50 & 13,6 & 43,2 & 826 \\
\hline $25 / 1$ & Domates yaprağ 1 & 3,26 & 4,10 & 5,40 & 225 & 14,6 & 17,5 & 17,2 & 3474 \\
\hline $25 / 2$ & Patlıcan yaprağ 1 & 9,33 & 4,30 & 5,10 & 121,9 & 14,3 & 8,00 & 10,7 & 2506 \\
\hline 26 & Akdarı başak & 6,12 & 5,00 & 5,40 & 84,5 & 5,10 & 6,50 & 14,1 & 1091 \\
\hline 27 & Zeytin yaprağ & 3,67 & 3,30 & 5,50 & 59,1 & 5,10 & 0,70 & 0,90 & 1165 \\
\hline
\end{tabular}

Cd: Bitki örneklerinin Cd kapsamları 2.2-6.7 $\mathrm{mgkg}^{-1}$ arasında saptanmıştır. Çiçek ve Koparal (2004) kritik Cd değerinin bitkiler için $5 \mathrm{mgkg}^{-1}$ olarak bildirmişlerdir. Havuçta ise sebzeler için 
belirtilen $0.10 \mathrm{mgkg}^{-1}$ 'in üzerindedir. Kuzeybatı yönünde yer alan (21-27 nolu örnek grupları) örnekler değerlendirildiğinde farklı bitki türlerine rağmen toplam $\mathrm{Cd}$ değerleri arasında belirgin bir farklılık bulunmamıştır. Hâkim rüzgâr yönündeki tarım alanları örneklemelerinde (zeytin, akdarı, domates, patlıcan, akdarı, , mısır bitkilerinin yaprakları ile susam tane) Cd değerlerinin bitkiler için tanınan sınır değerlere yakın veya biraz üzerinde bulunması dikkat çekicidir. Bölgede hakim rüzgar yönü ile 2. sıklıkla esen rüzgar yönü dışında GB yönlü rüzgar doğrultusunda ve santralden en uzak noktadan alınan tütün örneğinde $5.4 \mathrm{mgkg}^{-1} \mathrm{Cd}$ belirlenirken, iğne yapraklılarda $2.5 \mathrm{mgkg}^{-1}$ olarak saptanmış olması tarımsal faaliyetlerin girdilerinin yan etkisi olarak değerlendirilebilir.

Alloway (1995), bitkilerin Cd düzeylerinin $0.1-1 \mathrm{mgkg}^{-1}$ arasında değiştiğini ve bitkilerin Cd alınımını etkileyen en önemli toprak faktörlerinden birinin toprak $\mathrm{pH}$ 'sı olduğunu belirtmiştir. Kara yosununda $5.4 \mathrm{mgkg}^{-1} \mathrm{Cd}$ saptanmıştır. Bu değer çalışma alanında yapılan bir araştırmada kara yosunu için 0.56-1,50 ugg $^{-1}$ arasında bulunmuştur (Uğur vd., 2004).

Fe: Bitki örneklerinin Fe içerikleri orman ve tarım vejetasyonuna bağlı olarak önemli ayrım göstermektedir. Değerler 45.9-5500 $\mathrm{mgkg}^{-1}$ arasında değişim göstermektedir. Bölgedeki hakim rüzgar ile 2. sıklıkla esen rüzgar istikametinde toplanmış yaprak örneklerinde saptanmış olan Fe değerleri, anız örnekleri hariç, bitkiler için verilen kritik değerler içinde kalmaktadır (50-200 $\mathrm{mgkg}^{-1}$ ) ( Çiçek ve Koparal, 2004). Anızlarda saptanan değerler bitki kritik değerlerine göre 2-4 kat daha fazla olabilmektedir (4, 5, 7/1, 14 nolu örnekler). Anızlardaki Fe değerlerinin yüksekliğinin tarım aletleri kullanımı sırasında oluşan bulaşmadan kaynaklanması olasıdır. Santrale $12 \mathrm{~km}$ uzaklıkta olan ormanlık alanda kaya üzerinden alınan karayosununda $\mathrm{Fe}$, en yüksek değer olan $5500 \mathrm{mgkg}^{-1}$ saptanmıştır. Uğur vd. (2004) Yatağan Termik santraline farklı uzaklıktaki örnekleme noktalarından topladıkları karayosunlarının Fe kapsamının oldukça yüksek olduğunu, bunun nedeninin de hem toprakların $\mathrm{Fe}$ içeriğinin yüksek olmasından hem de kömürün yanarken $\mathrm{Cr}, \mathrm{Pb}$ ve $\mathrm{Hg}$ ile birlikte $\mathrm{Fe}$ 'in de atmosfere yayılması olduğunu bildirmişlerdir.

$\mathbf{C u}$ : Bölgede toplanmış olan farklı bitki dokularındaki toplam $\mathrm{Cu}$ değerleri genellikle normal değerlerden düşük bulunmuştur. Bitkilerin $\mathrm{Cu}$ kapsamı genelde $2-20 \mathrm{mgkg}^{-1}$ arasında değişmektedir (Güneş vd. 2000). Örneklerin toplam $\mathrm{Cu}$ değerleri 1.8-15,6 $\mathrm{mgkg}^{-1}$ arasında saptanmış olup, kritik değerin bir hayli altında bulunmaktadır (100 $\left.\mathrm{mgkg}^{-1}\right)$ (Çiçek ve Koparal, 2004). En yüksek değer 15.6 $\mathrm{mgkg}^{-1}$ ile karayosununda saptanmıştır. Bu sırayı domates ve patlıcan yaprakları ile tane susamda belirlenen değerler geriden takip etmiştir.

Uğur vd. (2004) Yatağan santraline farklı uzaklıktaki örnekleme noktalarından aldıkları karayosunlarının Cu kapsamlarını 14.01 ile18.60 ugg $^{-1}$ arasında bulmuşlardır.

Zn: Araştırma alanından alınan bitki örneklerinin $\mathrm{Zn}$ kapsamları 0,7-56,9 $\mathrm{mgkg}^{-1}$ arasında, kritik değerlerin altında yer almaktadır $\left(80-200 \mathrm{mgkg}^{-1}\right)$. Buna karşın havuçta bulunan $\mathrm{Zn}$ değeri yenilmesine izin verilebilir sınır olan $15 \mathrm{mgkg}^{-1}$ in üzerinde belirlenmiştir (Çiçek ve Koparal, 2004). Kara yosununda $\mathrm{Zn}$ değeri $11.4 \mathrm{mgkg}^{-1}$, dır. Uğur vd (2004) aynı çalışma bölgesinden aldıkları karayosunu örneklerinde veritabanı düzeyde $89.04 \mathrm{ugg}^{-1} \mathrm{Zn}$ belirlemişler buna karşılık santrale yakın karayosunu örneklemelerinde 147-166 ug g ${ }^{-1}$ arasında Zn saptamışlardır.

S: Santralden yayılan emisyonların bitkiler üzerine zararlarının en etkili olduğu element kükürttür. Ormanlık ve tarım alanından alınan örneklerin ayırımına bakıldığında şu farklılıklar izlenmiştir. İğne yapraklı ağaçlardan alınan örneklerde en yüksek değer güney yönlü hakim rüzgar yönünde, santralden $10 \mathrm{~km}$ uzaklıkta bulunan ormanlık alandan alınan (9 nolu örnek) kızılçam ibresinde $1876 \mathrm{mgkg}^{-1} 2$ dır. 1984-1985 yıllarında Bencik dağındaki ormanlardaki kızılçamlarda (Pinus Brutia) Yatağan Termik santralinden kaynaklanan emisyonlarla meydana gelen etkilenmede zarar görmüş ve çok zarar görmüş 1 yaşlı çam ibrelerinde ortalama değerler 2581-5826 $\mathrm{mgkg}^{-1}$ arasında, 2 yaşındaki çam ibrelerinde ise 3682-4313 $\mathrm{mgkg}^{-1} \mathrm{~S}$ olarak belirlenmiştir. (Kantarcı ve Müezzinoğlu, 1997). Bölgedeki Yatağan Orman İşleri Müdürlüğü’nden alınan bilgilere göre bu alandaki çamların 13 yıldır büyüme göstermediği, hep aynı boyda kaldıkları belirtilmiştir. Arazide ağaçlar incelendiğinde ağaçların 30 yaşında olmasına rağmen 30 yıllık gibi gözükmediği gözlenmiştir. Ayrıca yeni jenerasyonun yetişmediği Yatağan Orman Müdürlüğü tarafından belirtilmiştir (Yatağan Orman İşleri 
Müdürlüğü, Sözlü görüşme, 2002). İğne yapraklı örneğin alındığı 8 nolu alandan kaya üzerinde bulunan kara yosunu örneği de alınmış ve $\mathrm{S}$ miktarı $2330 \mathrm{mgkg}^{-1}$ olarak belirlenmiştir. Bu değer oldukça yüksek olmakla birlikte tarım ürünlerinde daha yüksek değerler de saptanmıştır. Tarım ürünlerinden zeytin bitkisi yapraklarında en yüksek S değeri santralden $1 \mathrm{~km}$ uzaklıkta olan 22 nolu örnekte saptanmıştır (2131 $\left.\mathrm{mgkg}^{-1}\right)$. Bu değeri sırasıyla diğer zeytin yaprak örneklerinin değerleri,

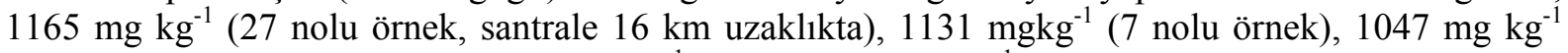
(16 nolu örnek, santrale yakın), $955 \mathrm{mg} \mathrm{kg}^{-1}$ (1 nolu), $816 \mathrm{mgkg}^{-1}$ (24) nolu örnek, kömür yataklarına $100 \mathrm{~m}$ mesafede) izlemiştir. Diğer tarım ürünlerine bakıldığında 19 nolu örnek alanından alınan havuç yaprağında $4011 \mathrm{mgkg}^{-1} \mathrm{~S}$ saptanırken, en düşük değer havucun kökünde saptanmıştır. Bu alanın özelliği linyit depolanma alanından gelen suyun sulama amaçlı kullanılması dolayısıyla kömürden yıkanan S'ün bitkiye kolaylıkla ulaşması sonucu yüksek değer saptandığı düşünülmektedir.

Domates ve patlıcan bitkilerinin yaprak örneklerinde (25 nolu örnek) S değerleri sırasıyla 3474 ve $2506 \mathrm{mgkg}^{-1}$ olarak belirlenmiştir. Bu alan santrale $6 \mathrm{~km}$ uzaklıkta olup gaz zararlarına en fazla uğrayan alandır. Bunu $2440 \mathrm{mgkg}^{-1} \mathrm{~S}$ içeriği olan tütün yaprağ 1 takip etmiştir ki bu örnek (6 nolu) santralden oldukça uzak etkisiz alan gibi görünmekle beraber 3. sıklıkla esen rüzgar yönünde bulunan örnekleme noktasından alınmıştır.

Diğer bitki örneklerinde belirlenen S değerleri şu şekildedir: Piyam (yabani ot) $1856 \mathrm{mg} \mathrm{kg}^{-1}$ (16 no'lu örnek, santrale en yakın örneklerden biri), akdarı $1091 \mathrm{mgkg}^{-1}$ (26 no'lu örnek, santrale $8 \mathrm{~km}$ uzaklıkta zararların önceleri görüldüğ̈̈ ancak filtre takıldıktan zararlanmaların azaldığı alan), susam $248 \mathrm{mgkg}^{-1}$ (21 no'lu örnek, santralin güney yönünde $721 \mathrm{~m}$ mesafede), 18 nolu alandan alınan mısır bitkisinin (yaklaşık $2.5 \mathrm{~km}$ ) taze yeşil üst yaprağında $1931 \mathrm{mgkg}^{-1}$, alt yaprağında $2208 \mathrm{mgkg}^{-1}$ olarak $\mathrm{S}$ belirlenmiştir. $\mathrm{Bu}$ alanın güçlü emisyon bölgesinin bulunması yanında zaman zaman kül barajından sulama yapılmasının $S$ değerlerinin yükselmesine neden olduğu düşünülmektedir.

Alınan buğday anızı örneklerinde S miktarları en yüksek 4 nolu örnek olmak üzere (696 mgkg$\left.{ }^{1}\right), 23$ no'lu (547 mg g${ }^{-1}$ ) (santrale $2 \mathrm{~km}$ uzaklıkta), 14 no'lu (507 mg kg$\left.{ }^{-1}\right), 7$ no'lu örnek (367 mgkg$\left.{ }^{1}\right)$ ve 16 no'lu (287 $\left.\mathrm{mgkg}^{-1}\right)$ (santrale $1.5 \mathrm{~km}$ uzaklıkta) örneklerde saptanmıştır. Mısır anızı örneklerinde $\mathrm{S}$ miktarları buğday anızı değerlerinden daha yüksek olduğu belirlenmiştir. En yüksek değer $1259 \mathrm{mgkg}^{-1}$ ile 10 no'lu örnekte belirlenmiştir.

\section{Sonuç ve Öneriler}

Yatağan Termik Santralinin etrafı tepe ve dağlarla çevrili küçük bir ovada kurulmuş olması, 120 m yükseklikteki santral bacalarından salınan emisyonların rüzgâr etkisiyle çevreye yayılmasına ve tarım alanları ve ormanlık alanlarda sorunlara yol açmasına neden olmaktadır. Diğer yandan santralde kullanılan linyitlerin düşük kalorili olması nedeniyle yüksek kül içermesi, yine yüksek S kapsamı, santralin baca filtrelerinin verimsiz çalışmasından dolayı çevreye kül ve toz dağılması, küllerin taşınımı ve aktarımı sırasında kaçakların meydana gelmesi sorunların esas kaynağını oluşturmaktadır. Ayrıca yanma sonucu kömürün yapısında bulunan ağır metallerde açığa çıkmaktadır.

$\mathrm{Bu}$ araştırma santral çevresindeki tarım ve orman topraklarının santralin bacalarından çıkan emisyonlardan kaynaklanabilecek olası ağır metal kirliliğini ortaya koymak ve elde edilen sonuçlarla etkin olabilecek bir veri tabanı elde edilmesini sağlayacak bir alt yapı oluşturmak amacıyla yürütülmüştür.

Araştırma kapsamında toprak için elde edilen sonuçlar şu şekildedir:

1. Toprak tekstürleri heterojen bir dağılım göstermiştir.

2. Toprak örneklerinin $\mathrm{pH}$ 'larının ormanlık alanlarda genellikle asidik karakterde, tarım alanlarında ise nötr veya alkalin karakterde olduğu belirlenmiştir.

3. Topraklar tuz içeriklerine göre tuzsuz özellik göstermiştir.

4. Orman toprakları kireç içermezken, tarım topraklarının bir kısmı kireçsiz, bir kısmı da, çok fazla kireçli bulunmuştur.

5. Toprakların organik madde kapsamları orman topraklarında yüksek (>\%5), tarım topraklarında ise yetersiz bulunmuştur. Buna bağlı olarak da azot değerleri düşüktür. 
6. Toprakların toplam ağır metal kapsamları incelendiğinde genelde santralin güney, güney batısı ve kuzeybatısındaki topraklarda ağır metal içeriğinin yüksek bulunduğu ve bu değerlerin santrale olan uzaklığa değil hâkim rüzgâr yönlerine bağlı olduğu belirlenmiştir.

7. Toprakların ekstrakte edilebilir ağır metal kapsamları güneybatı ve güney yönünde yoğunlaşmakla birlikte, santralin güneydoğusunda yer alan 6 nolu örnekte diğer örneklere göre göreceli olarak yüksek bulunmuştur. Ayrıca santrale en yakın yerden alınan 1 nolu toprak ve bitki örneklerinde sonuçlar göre oldukça yüksek bulunmuştur.

Araştırma kapsamında bitki için elde edilen sonuçlar ise şu şekildedir: Ağır metallerin bir kısmı bitki besin maddesi olmamasına rağmen biyolojik döngüde yer almakta ve bitkiler tarafindan alınarak biriktirilmektedir. Bazılarının bitkide henüz bir fonksiyonunun olup olmadığı saptanamamıştır. Araştırma bölgesinde, $\mathrm{Pb}$ için bitki örneklerinde saptanan değerler değişkenlik göstermekle beraber yenilebilir olmasından dolayı havuç ve susam örneklerinin $\mathrm{Pb}$ değerleri meyve ve sebzelerde izin verilebilir en yüksek değer olan $0.5 \mathrm{mgkg}^{-1}$ 'n üzerindedir. Havuçta yine $\mathrm{Cu}$ için verilen sınır değerin $\left(5 \mathrm{mgkg}^{-1}\right)$ üzerinde, $6.30 \mathrm{mgkg}^{-1}$, susamda $9 \mathrm{mgkg}^{-1}$ belirlenmiştir. Cd'un sebzeler için sınır değeri $0.10 \mathrm{mgkg}^{-1}$ olmakla beraber bu değer havuçta $4.80 \mathrm{mgkg}^{-1}$ 'dir. Yine havuçta bulunan Zn (21.9 $\left.\mathrm{mgkg}^{-1}\right)$ sınır değer olan $15 \mathrm{mgkg}^{-1}$ 'ı üzerindedir. Havuç bitkisi Bergmann (1992)'a göre önemli düzeyde ağır metal biriktiren bitki sınıfına girmektedir. Kömür depolama alanından gelen su ile sulanarak yetiştirilen bu bitkide değerlerin yüksek olmasının bu suyun sulama için uygun olmadığı ve birikim sorununa yol açtığı görülmektedir. Alınabilir S değerleri iğne yapraklı ormanlık alanlardan alınan örneklerde hâkim rüzgar doğrultusunda diğerlerine göre daha fazla saptanmıştır. Santralin güneyinde yer alan ve santralin ilk zararlarının görüldüğü alanlardır. Ormanlık alandan alınan karayosunu örneğinde ağır metal değerleri ve alınabilir $S$ oldukça yüksek bulunmuştur. Karayosunlarının hava etkileşimine en açık bitkiler olduğu ve ağır metal biriktirdikleri bilinmektedir.

Ülkemizdeki araştırmaların eksik yönlerinden birisi de aynı alanda uzun yılları içeren çalışmaların olmayışı ya da çok az olmasıdır. Bu araştırmada elde edilen sonuçlar ülkemizde farklı araştırmacılar tarafından da olsa aynı alanda birbirinin ardı sıra, farklı yıllarda yapılan araştırmalara bir katkı sağlayacak ve ileriki çalışmalar için yararlı bir veri tabanı oluşturacaktır.

\section{Kaynaklar}

Aktaş, M. 1995. Bitki Besleme ve Toprak Verimliliği. A.Ü. Ziraat Fak. Yayın No: 1429. Ankara.

Alloway, B.J. 1995. Heavy Metals In Soils. Blackie Academic and Professional, London, p.354

Alloway, W.H. 1968. Agronomic controls over environmental cycling of trace elements. Adv. Argon. 20: 235-274.

Aubert, H. ve Pinta, M. 1977. Trace Metals In: Soil. Elsevier Sci. Publ. Co., Amsterdam.

Baba, A. 2002. Assesment of radioactive contaminants in by- products from Yatagan (Mugla- Turkey) coal-fired power plant, Environ Geol, 41,916-921.

Baba, A. 2003. Geochemical assessment of environmental effects of ash from Yatagan (MuglaTurkey) thermal power plant, Water, Air, \& Soil Pollution, 144, pp. 3-18.

Bergman, W. 1992. Nutritional disorders of plants-development, visual and analytical diagnosis. Jena: Gustav Fischer.

Çiçek, A. and Koparal, A. S. 2004. Accumulation of sulfur and heavy metals in soil and tree leaves sampled from the surroundings of Tunçbilek Thermal Power Plant. Chemosphere, 57, 10311036.

Dhane, S.S. ve L.M. Shukla. 1995. Zinc adsorption and its thermodynamics in soil series of Maharashtra, J. Indian Soc. Soil Sci. 43, 590.

Gentzis, T. ve F. Goodarzi. 1997. Trace Element Geochemistry of Brackish-Water Coals in the Central Alberta Plains, Canada. Energy Sources, Part A: Recovery, Utilization, and Environmental Effects, 19: 5, 493-505.

Günay, T. 1986. Muğla-Yatağan Termik Santralinin çevresinde bulunan ormanlara etkileri. Rapor. Orman Genel Müdürlüğü Toprak Laboratuarları, Eskişehir 
Güneş, A., Alpaslan, M. ve İnal, A. 2000. Bitki Besleme ve Gübreleme. Ankara Üniversitesi Ziraat Fakültesi, Yayın No:1514. Ankara.

Hakerlerler, H., Taysun, A., Okur, İ. ve Arslan, S. 1992. GAP bölgesi topraklarının ağır metallerinin birikimi. Tr. J. Of Engineering of Environ. Sci. 19: 423-431.

Haktanır, K., Arcak, S., Erpul, G. ve Tan, A. 1995. Yol kenarındaki topraklarda trafikten kaynaklanan ağır metallerin birikimi. Tr. J. Of Eng. Of Environ. Scien. 19, 423-431.

Jackson, M.L. 1962. Soil Chemical Analysis.Prentice Hall, Inc.New York.

Kacar, B. 1995. Toprak Analizleri. A.Ü.Z.F. Eğitim, Araştırma ve Geliştirme Vakfı Yayınları No: 3, 627-629, Ankara.

Kadıoğlu, Y.K. ve İ. Bayramin. 2007. Kütahya-Seyitömer çevresindeki kayaç ve toprakların jeolojik, petrografik ve jeokimyasal yönden irdelenmesi. Rapor. Ankara Üniv.

Kantarci, M. D. ve Muezzinoglu, A. 1997, 'Impact of the three lignite-fired power plants on the forests at Mugla region of Turkey. Regional and Global Scales', in S. Incecik, E. Ekinci, F. Yardim and A. Bayram (eds.), Environmental Research Forum, Vol. 7-8, Trans Tech Publication Switzerland, pp. 555-563.

Kantarc1, M.D. 2003. The Effects of Three Thermo Electric Power Plants on Yerkesik-Denizova Forests in Mugla Province (Turkey). Water, Air\&Soil Pollution, 3:211-219

Karaca, A. 1997. Afşin-Elbistan Termik Santralı Emisyonlarının Çevre Topraklarının Fiziksel, Kimyasal ve Biyolojik Özellikleri Üzerine Etkileri. Ankara Üniv. FBE, Ankara. Doktora Tezi.

Karaca, A., Kadıŏlu, Y.K., Bayramin, İ., Turgay, O.C., Türkmen, F. ve Sağlam, M., 2007. AfşinElbistan Termik Santralı Emisyonlarının Çevre Toprakları Üzerine Etkileri. Proje, (Yayınlanmamış) Ankara.

Karaca, A., Turgay, O.C., Karaca, S., Sağlam, M., Türkmen, F., Deviren, S. ve Türkmen, N. 2007. Seyitömer termik santralı emisyonlarının çevre toprakları üzerine etkileri. Proje, (Yayınlanmamış), Ankara.

Karayigit, A. I., Gayer, R. A., Querol, X., ve Onacak, T. 2000. Contents of major and trace elements in feed coals from Turkish coal-fired power plants. International Journal of Coal Geology 44:169-184.

Kloke, A. 1980. Orientierungtaden für tolerierbare gesamtghalte einger elemente in kulturboden. (Richwerte 80). Biologische Bundesantait for Land und Forstwirstchaft, Berlin.

Lindsay, W.L. ve Norvell, W.A., 1978. Development of a DTPA soil test for Zn, Fe, Mn and Cu. Soil Sci. Amer. J. 42 (3): 421-28.

Martin, M.H. ve P.J. Coughtrey. 1982. Biological monitoring of heavy metal pollution, Applied Science Publishers, London, p. 475.

Moen, J.E.T., Cornet, J.P. ve Evers, C.W.A. 1986. Soil protection and remedial actions. Criteria for decision making and standarization of requirements. 441-448. In: Contaminated Soil (ed. J.W. Assink and W,J, Wanderbink) Martinue Nijhoff Dordrecht).

Nuhoglu,Y. ve Bulbul, F. 2003. Türkiye'nin büyük termik santralleri küllerinin elemental analizi. J. Trace and Microprobe Techniques 21(4), 721-728.

Özbek, H., Kaya, Z., Gök, M. ve Kaptan, H. 1993. Toprak Bilimi. Ç.Ü. Ziraat Fakültesi Genel Yayın No: 73, Ders Kitapları No: 16.

Özbek, H.B. 1996. Yatağan Termik Santralı Emisyonlarının Etkileri. Ankara Üniversitesi, Fen Bilimleri Enstitüsü Yüksek Lisans Tezi, Ankara (yayınlanmamış).

Pacyna, J.M. 1982. Trace element emissions from coal and oil power plants in Eurape methodology of calculations. Norwegian Ins. For Air Research. Nilu Supplement Til Technics Raport No. 5/82. Ref. 24781.

Richards, L.A., 1954. Diagnosis and improvement of saline and alkalin soils. U.S. Dept. Agr. Handbook, No.60, 110-8pp.

Sağlam, T. 1997. Toprak Kimyası. Trakya Üniv. Tekirdağ Zir. Fak. Yayın No:190 
Sarıgül, M. 1991. Hava kirliliğinin Muğla-Yatağan yöresinde orman toprağı ve ağaçları üzerine etkisi. Ormancılık Araştırma Ens. Teknik Bülten, No. 217-248.

Sawidis, T., M.K. Chettri, A. Papaionnou, G. Zachariadis and J. Stratis. 2001. A study of metal distribution from lignite fuels using trees as biological monitors. Ecotox. Environ. Safe, 48: 27-35.

Schwertman, W., Fischer, W.R. ve Fecther, H. 1982. Spurenelemente in bodensequenzen. I. Zwei Brunerde-Podzol-Sequenzen aus fonschieferschutt. Z. Pflanzenern. Bodenk. 145: 181-196.

Türk Tabipleri Birliği 2000. Yatağan'da hava kirliliğinin değerlendirilmesi. TTB Raporu

Udo, E.J., Bohn, H.L. ve Tucker, T.C. 1970. Zinc adsorption by calcareous soils. Soil Sci. Soc. Am. Proc. 34, p. 405.

Uğur, A., G. Yener, M., Saç, M., Altınbaş, U., Kurucu, Y., Bolca, M. ve Özden, B. 2004. Vertical Distribution of the Natural and Artificial Radionuclides in Different Soil Profiles to Investigate Soil Erosion, Journal of Radioanalytical and Nuclear Chemistry, 259 (2): 265-270.

Usta, S. 1995. Toprak Kimyası. Ank. Üniv. Zir. Fak. Yayınları, Yayın No: 1387.

Ülgen, N., Eyüpoğlu, F., Kurucu, N. ve Talaz, S. 1989. Türkiye topraklarının bitkiye yarayışlı kükürt durumu. Toprak Gübre Araştırma Enstitüsü. Genel Yayın No: 209, Ankara.

Ward, N.I., Brooks, R.R. ve Reeves, R.D. 1974. Effect of lead from motor-vehicle exhausts on trees along a major thoroughfare in Palmerston North, New Zealand. Environ. Pollut., 6, 149-58.

Yıldız, T. 1996. Orhaneli termik santrali emisyonlarının etkileri. Ankara Üniv., FBE Yüksek Lisans Tezi, Ankara (yayınlanmamış). 